\title{
Size at birth and plasma insulin-like growth factor-1 concentrations
}

C H D Fall, A N Pandit, C M Law, C S Yajnik, P M Clark, B Breier, C Osmond, A W Shiell, P D Gluckman, D J P Barker

\begin{abstract}
Objective-To test the hypothesis that reduced fetal growth leads to altered plasma insulin-like growth factor-1 (IGF1) concentrations in childhood.

Design-A follow up study of 4 year old children whose birth weights were recorded, and of 7 year old children whose weight, length, head circumference, and placental weight were measured at birth. Setting-Pune, India, and Salisbury, England.

Subjects-200 children born during October 1987 to April 1989 in the King Edward Memorial Hospital, Pune, weighing over $2.0 \mathrm{~kg}$ at birth and not requiring special care, and 244 children born during July 1984 to February 1985 in the Salisbury Health District and still living there.
\end{abstract}

Main outcome measure-Plasma IGF-1 concentrations.

Results-In both groups of children, and consistent with findings in other studies, plasma IGF-1 concentrations were higher in taller and heavier children, and higher in girls than boys. Allowing for sex and current size, concentrations were growth and high blood pressure in later life.

(Arch Dis Child 1995; 73: 287-293)

Keywords: insulin-like growth factor-1, birth weight, systolic blood pressure.

Recent studies have shown that men and women who had reduced fetal growth have increased rates of cardiovascular disease ${ }^{12}$ and hypertension. ${ }^{34}$ One mechanism proposed as a link between reduced fetal growth and cardiovascular disease is persisting changes in secretion of and sensitivity to the hormones that regulate fetal growth, including insulin and insulin-like growth factor-1 (IGF-1). ${ }^{4-6}$ Low birth weight is associated with an increase of plasma insulin concentrations, and insulin resistance, in adult life. ${ }^{7-12}$ We recently studied glucose and insulin concentrations during an oral glucose tolerance test in 4 year old children in Pune, India, and 7 year old children in Salisbury, England. ${ }^{13} 14$ Children of low birth weight (Pune) or low ponderal index (weight/length ${ }^{3}$ ) at birth (Salisbury) showed evidence of reduced insulin sensitivity. We hypothesised that fetal undernutrition leads to insulin resistance which is present in childhood and persists into adult life.

As yet there are no comparable data for IGF-1. We have measured plasma IGF-1 concentrations in fasting blood samples taken during our studies of glucose and insulin metabolism in children, and examined the relationship of IGF-1 to birth weight, and other measurements of body size at birth. We have also examined the relationship of plasma IGF-1 concentrations to blood pressure.

\section{Subjects and methods}

PUNE

The study sample was 404 singleton children, born in the King Edward Memorial Hospital (KEMH) during October 1987 to April 1989 , weighing more than $2.0 \mathrm{~kg}$ at birth, and admitted to the routine postnatal wards (that is, they did not require special care). They were selected using random number tables

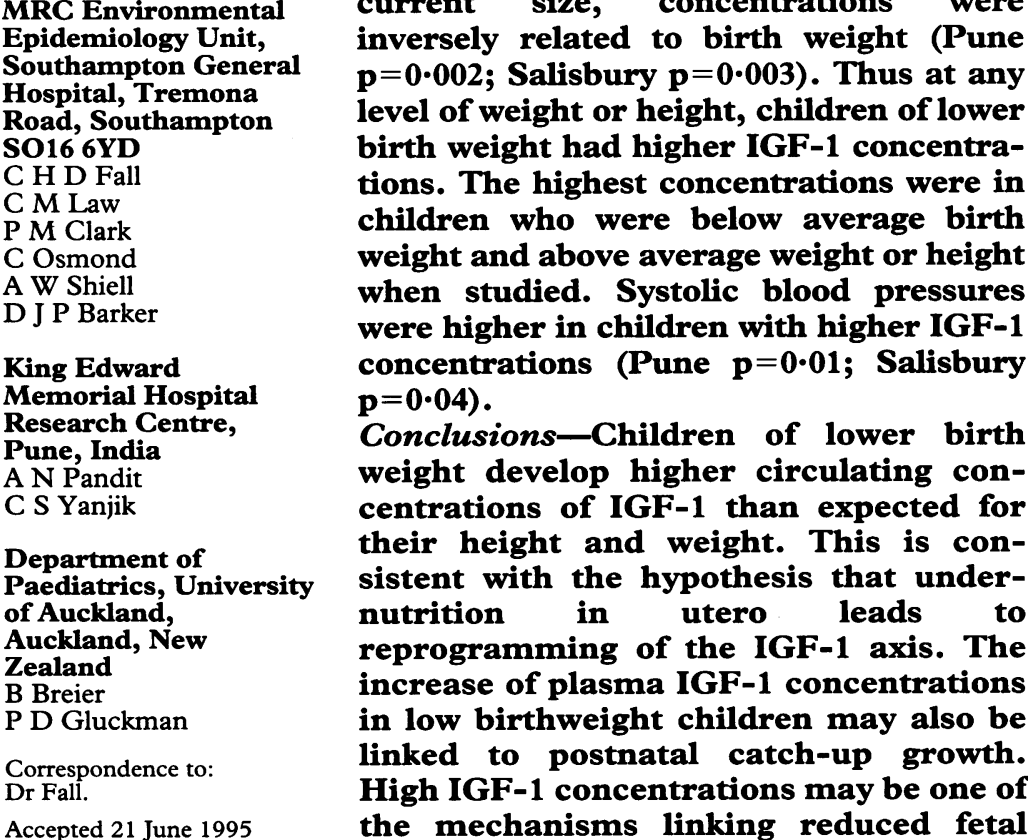

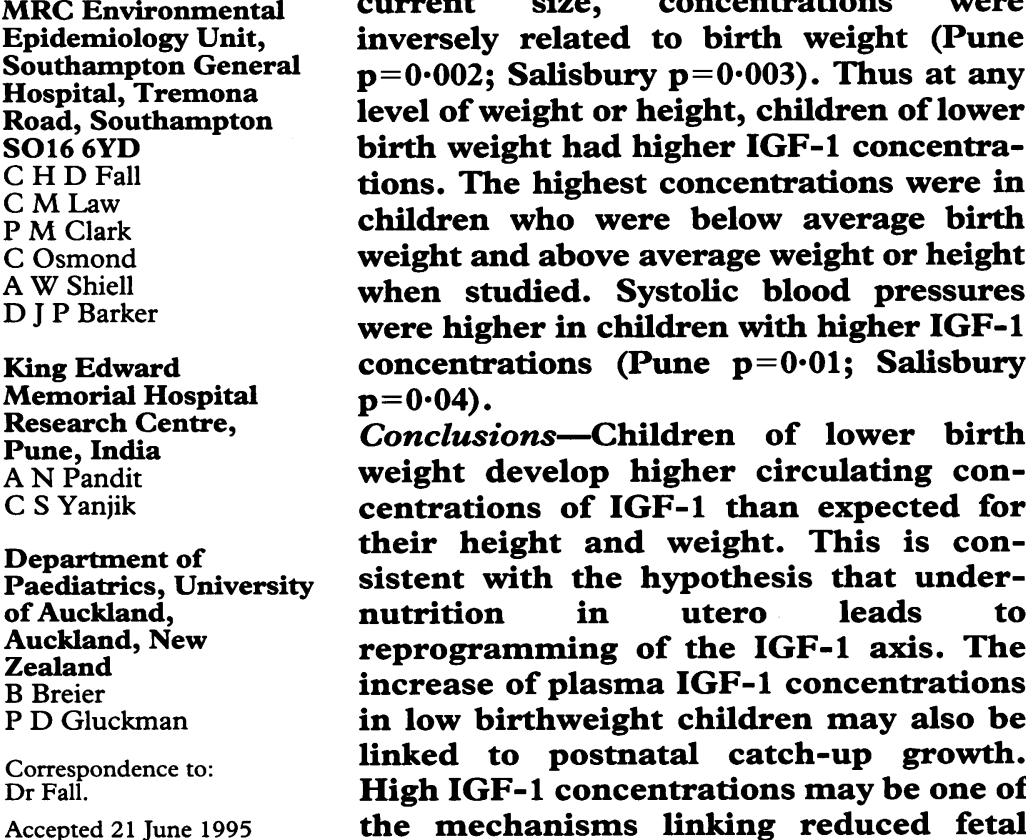

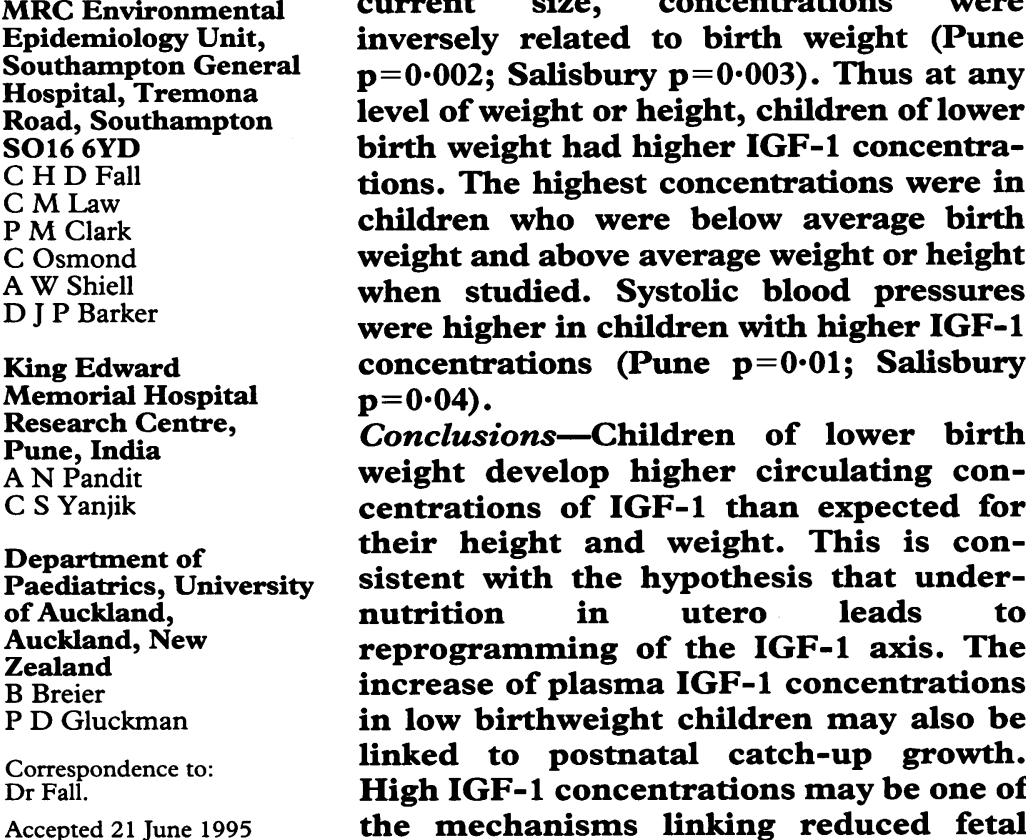

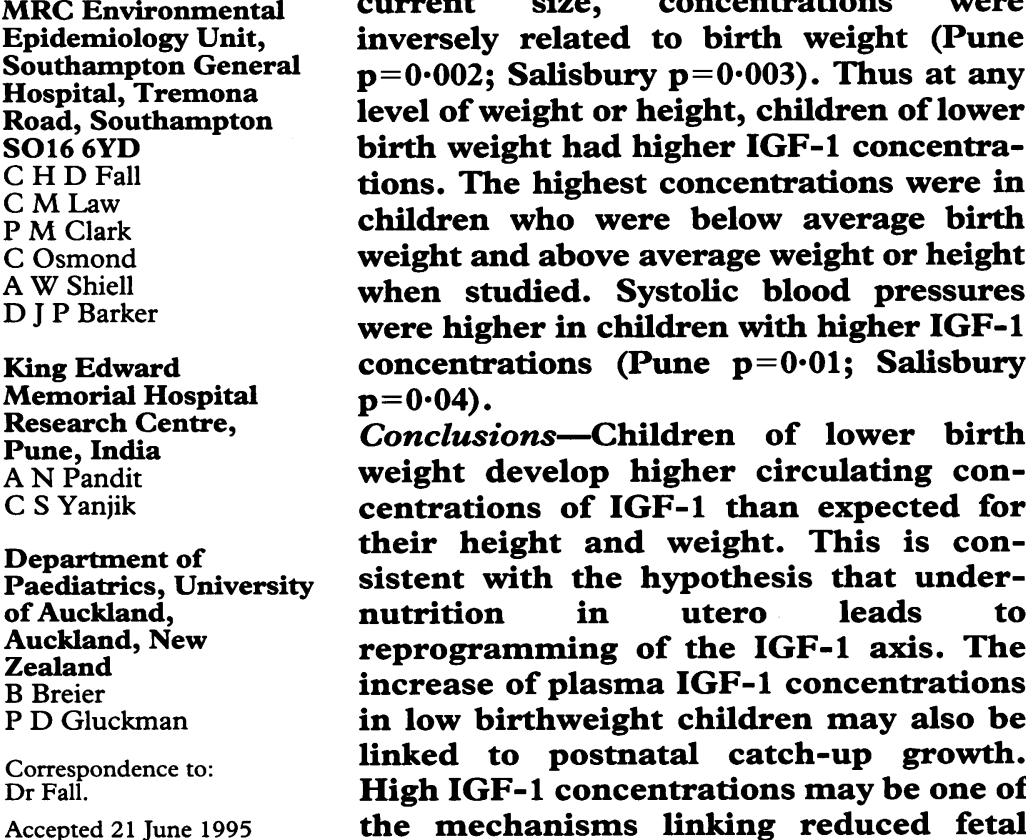

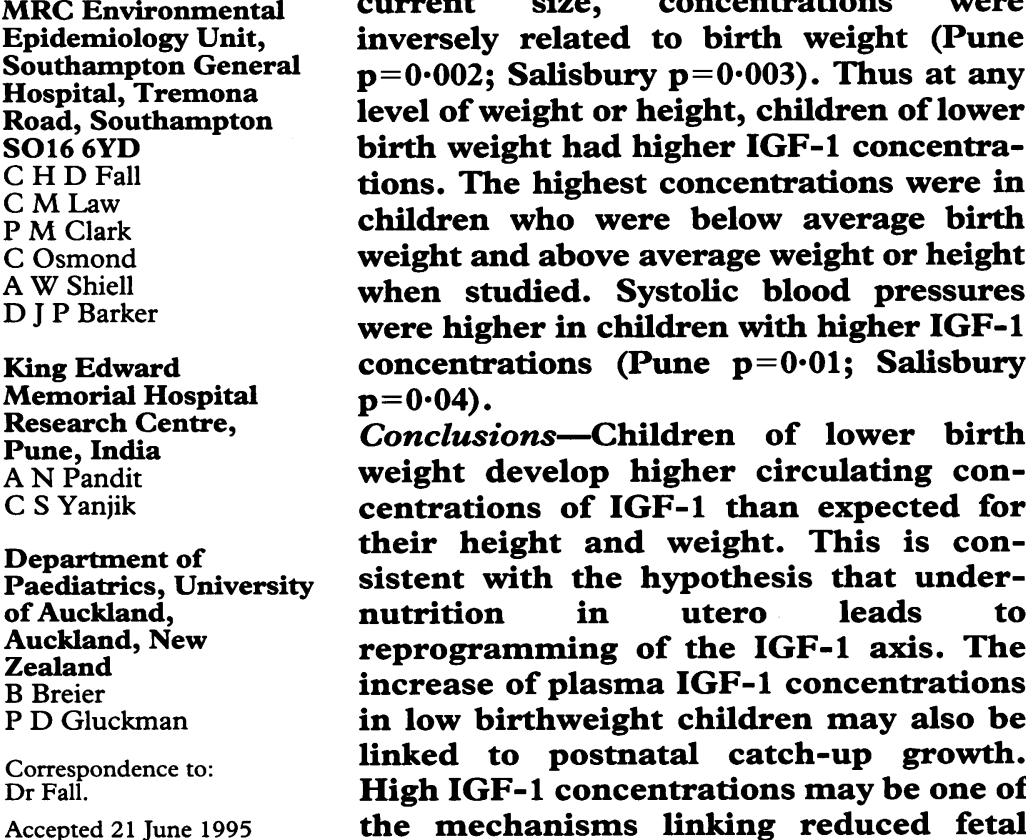

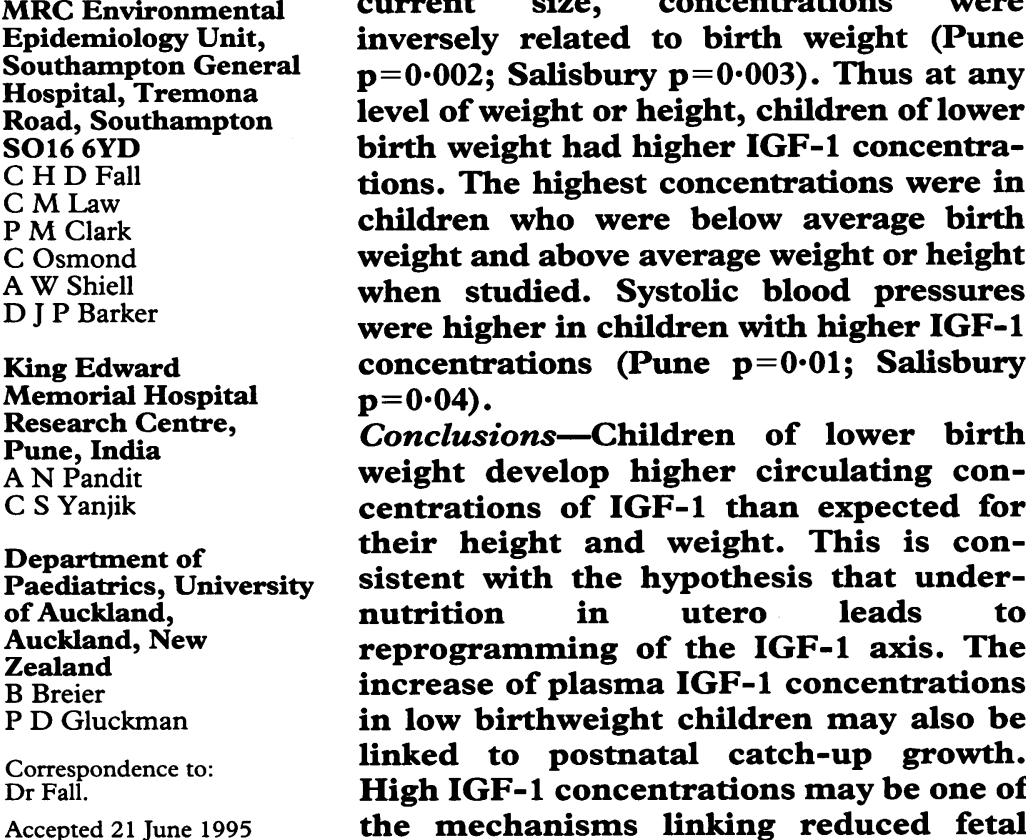

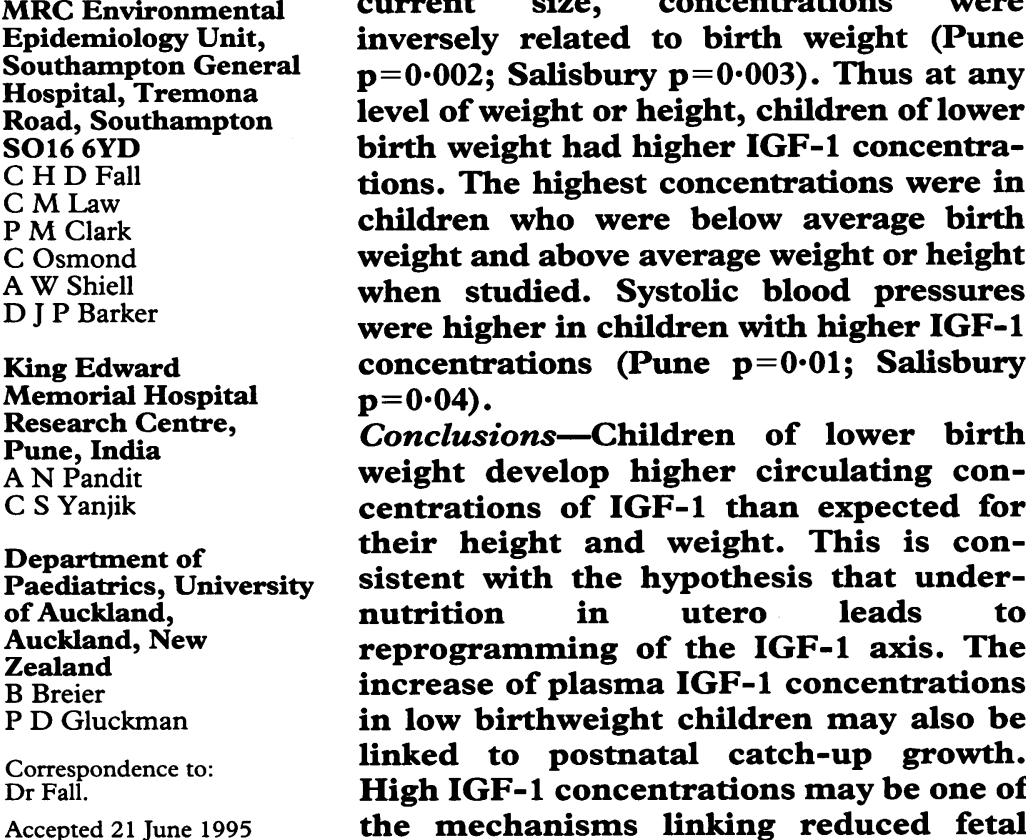

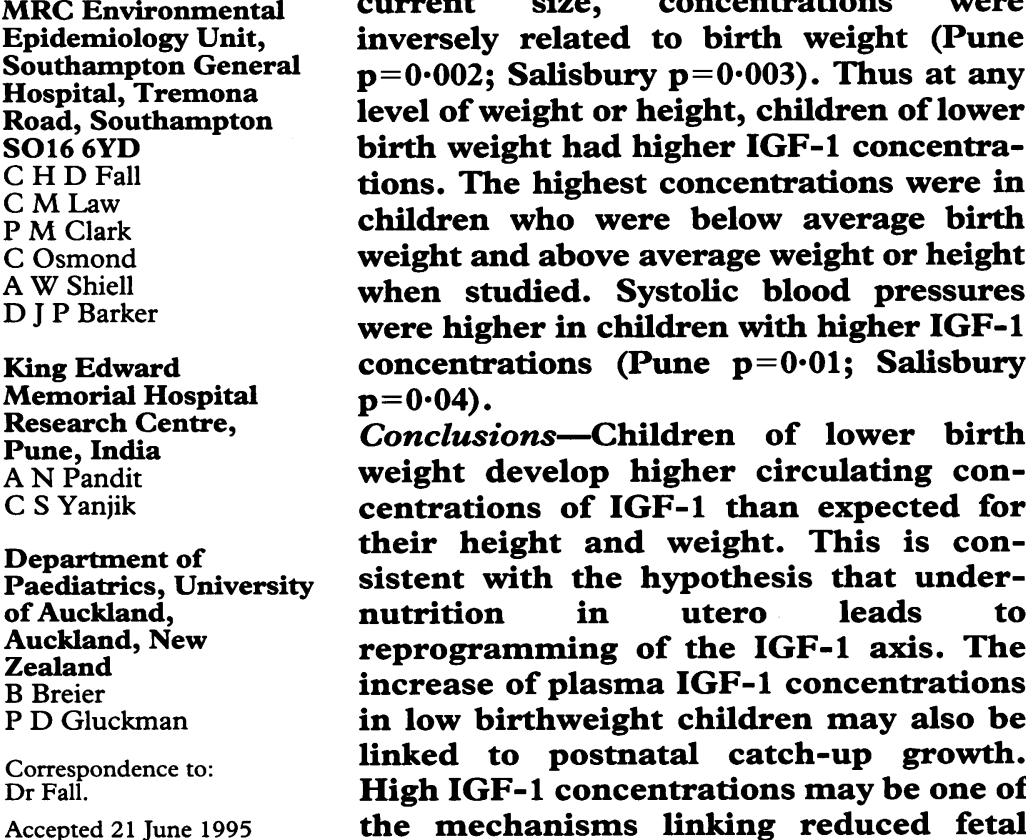

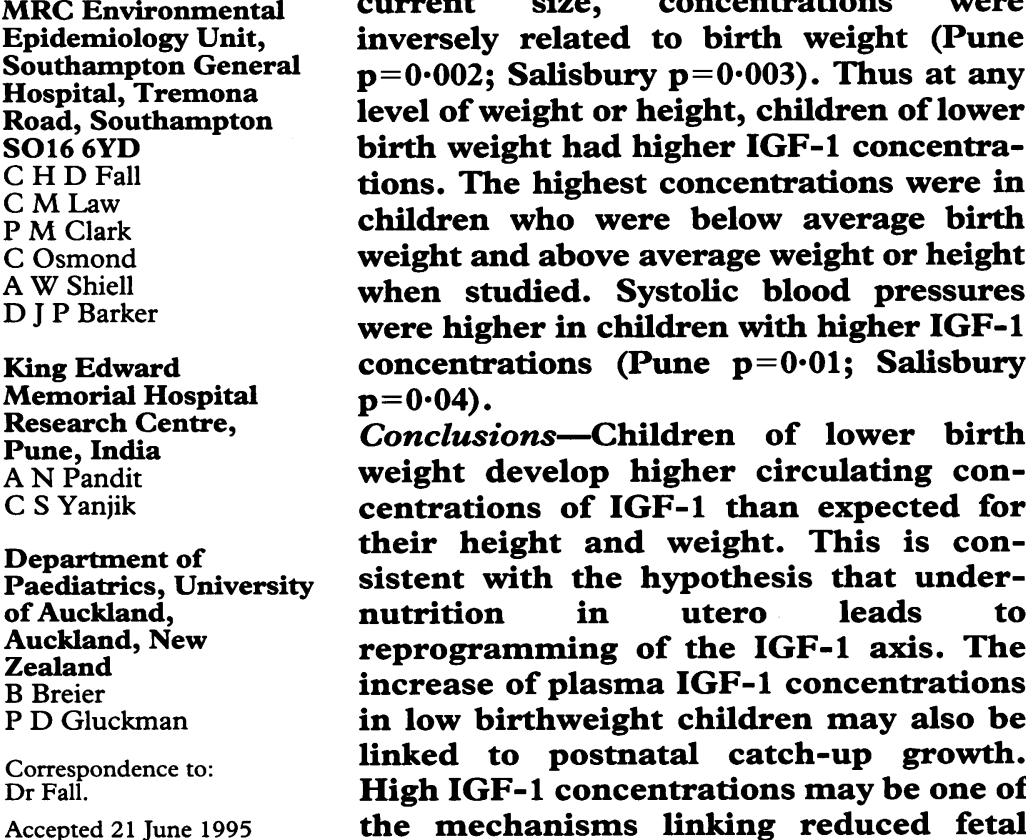

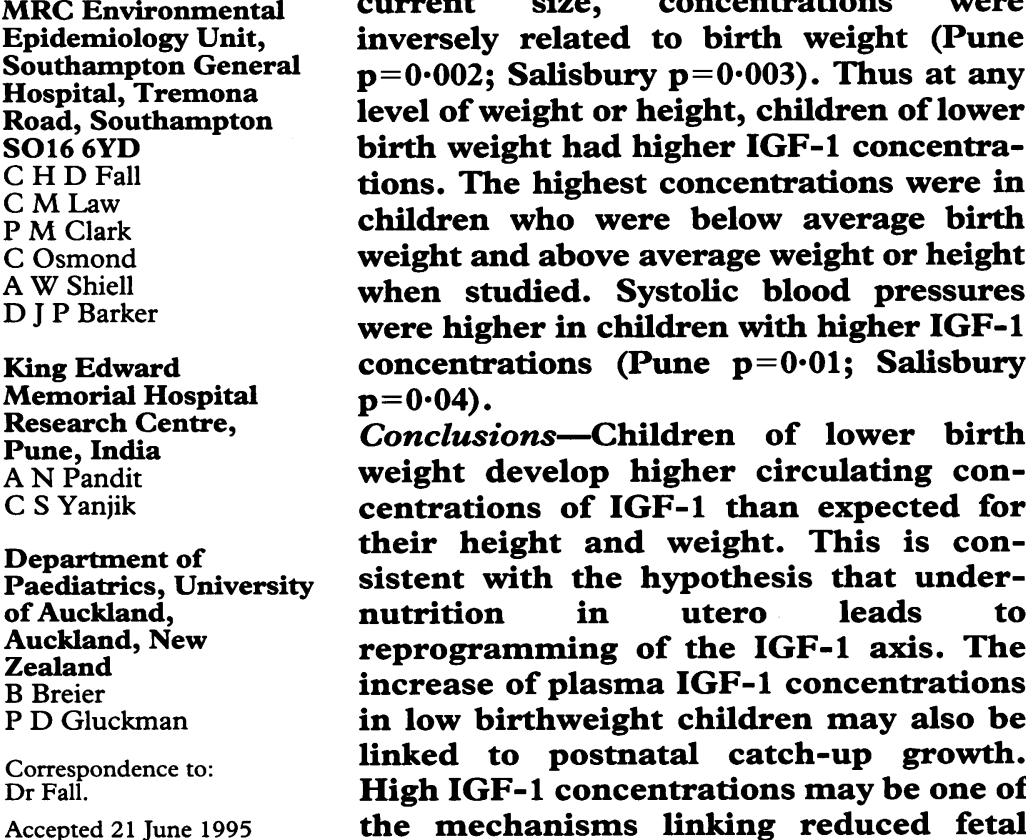

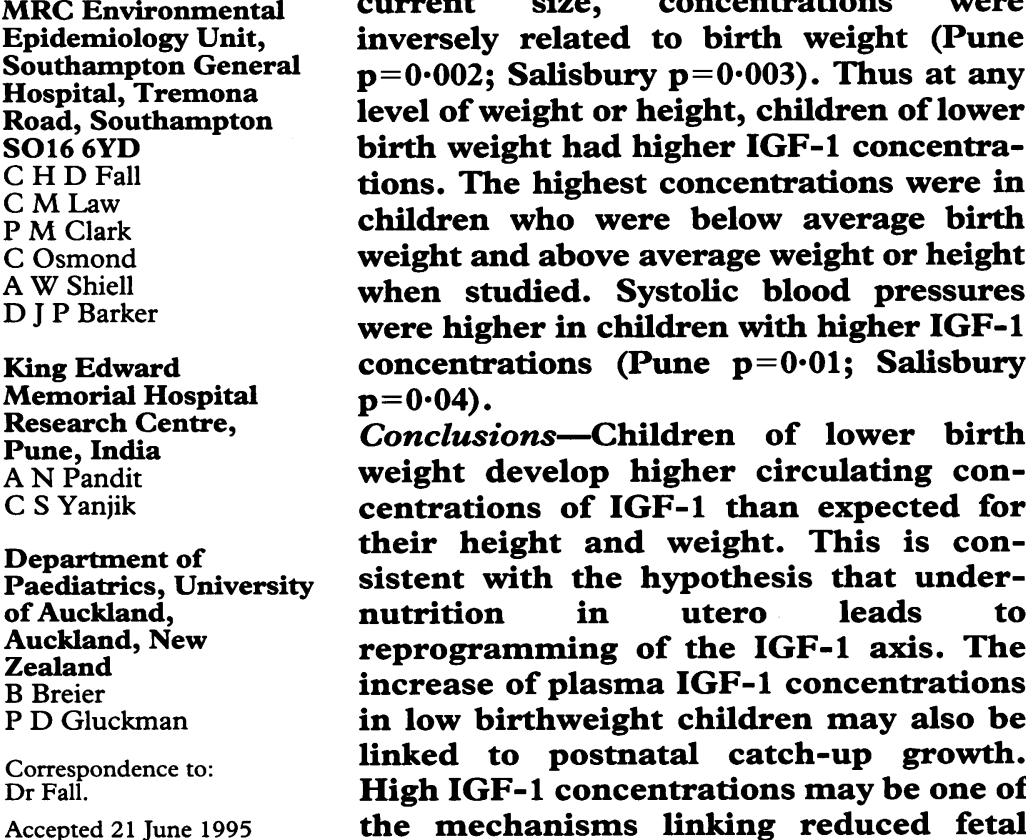

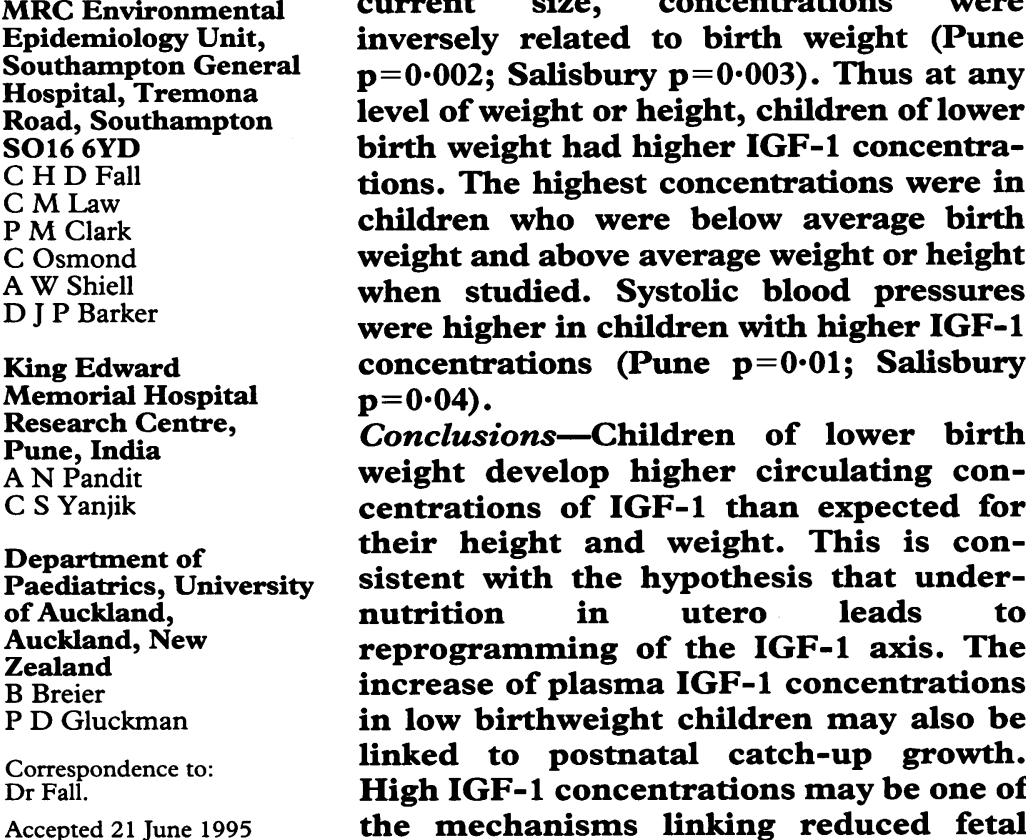

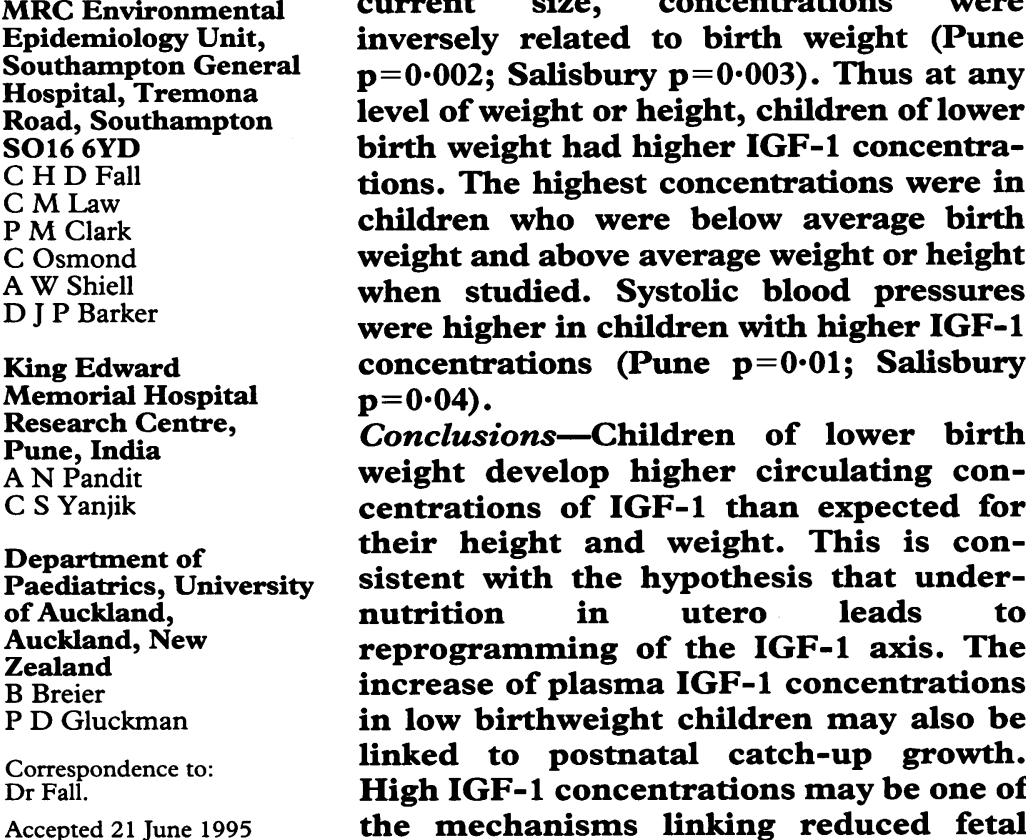

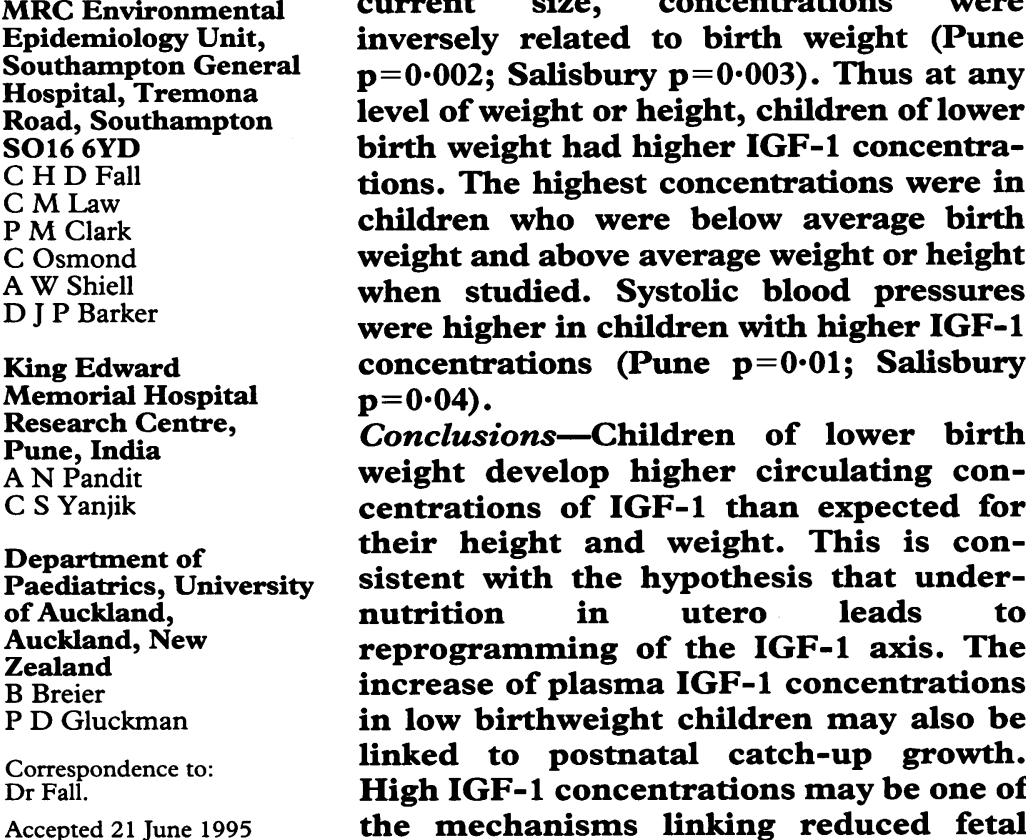

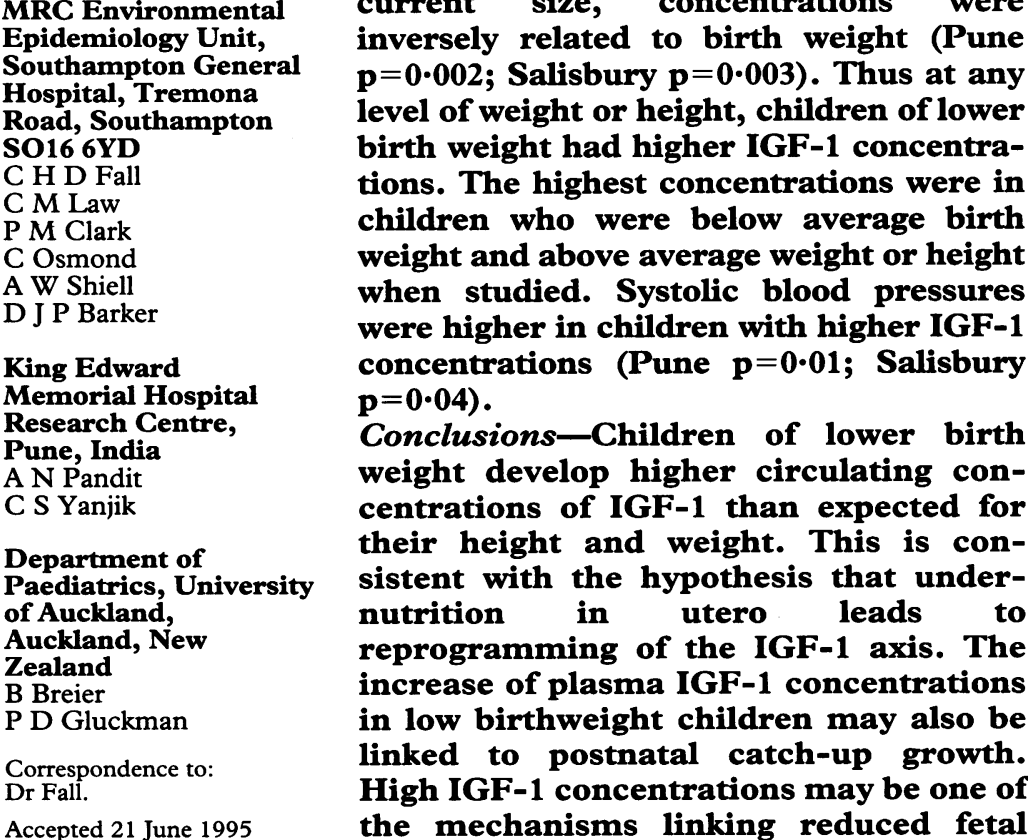

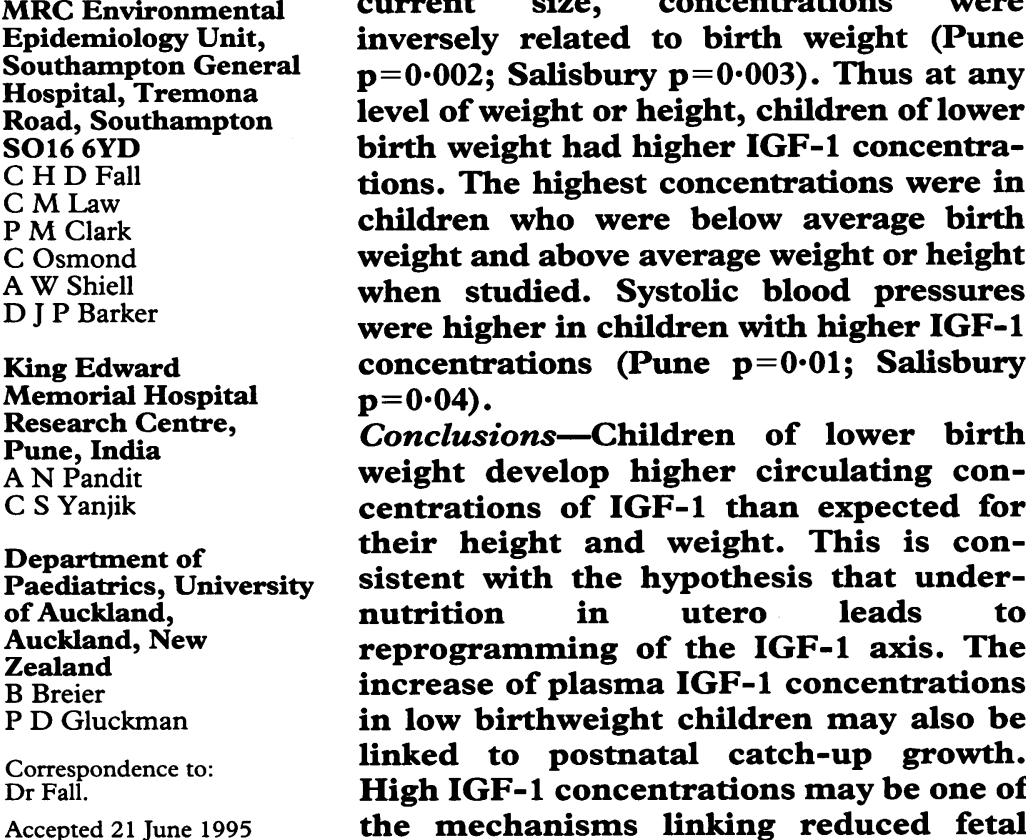

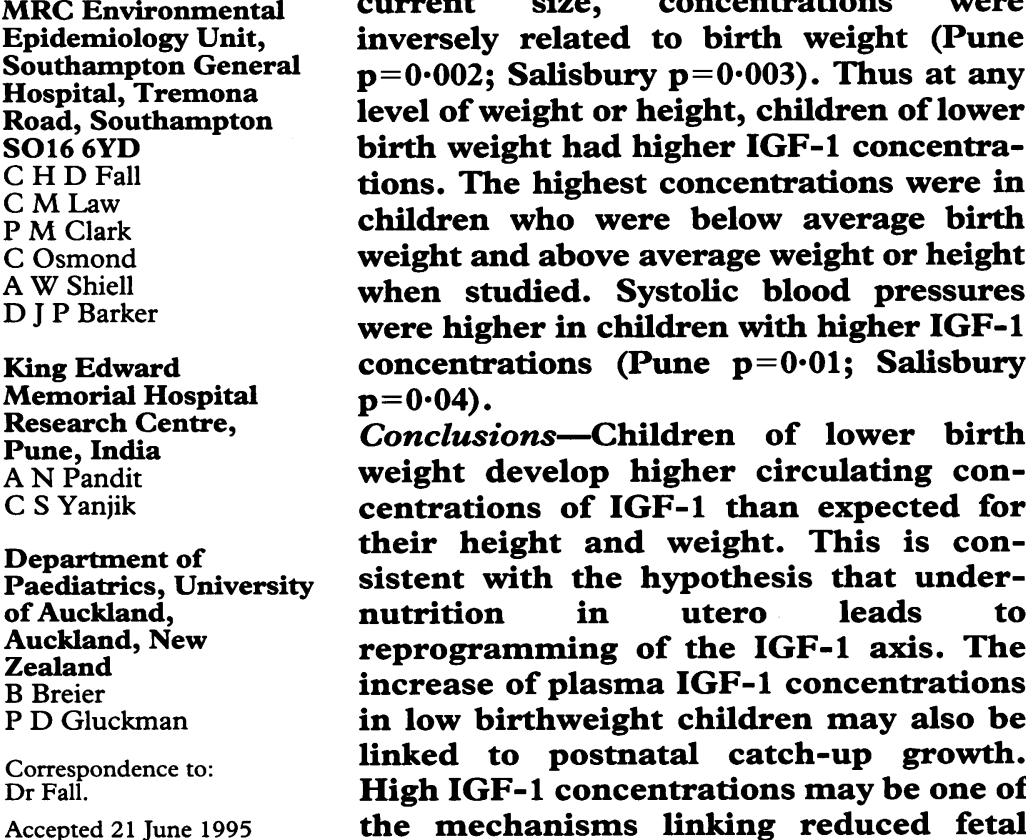

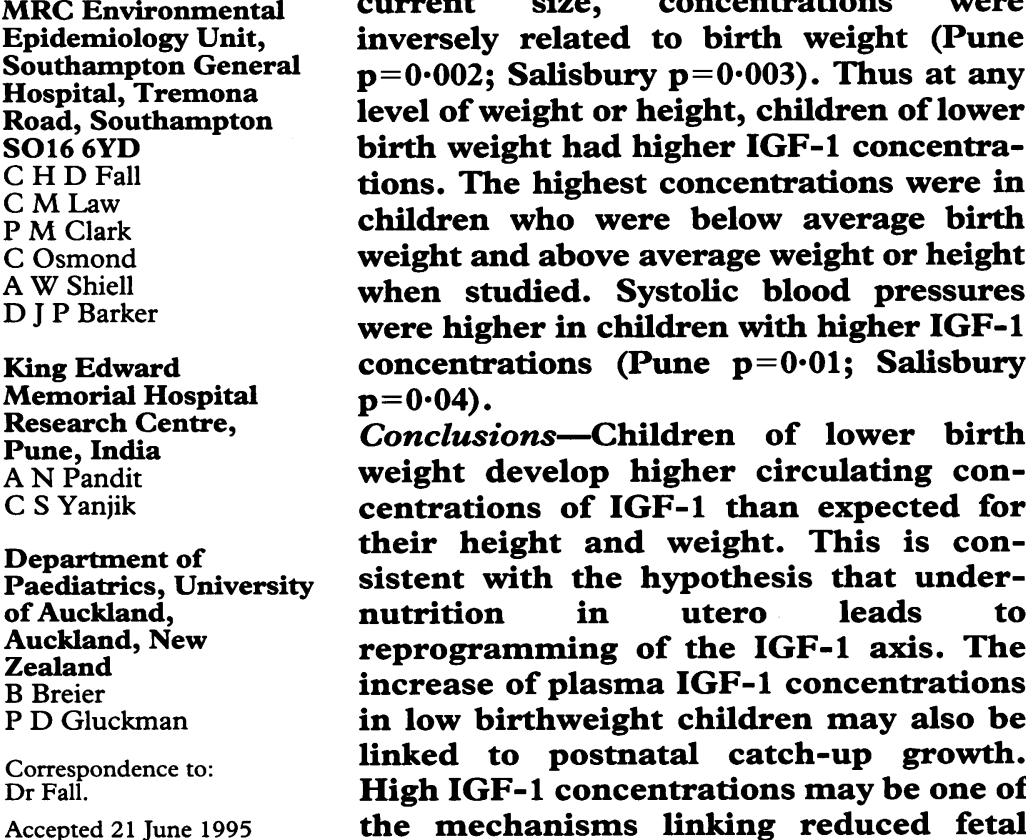

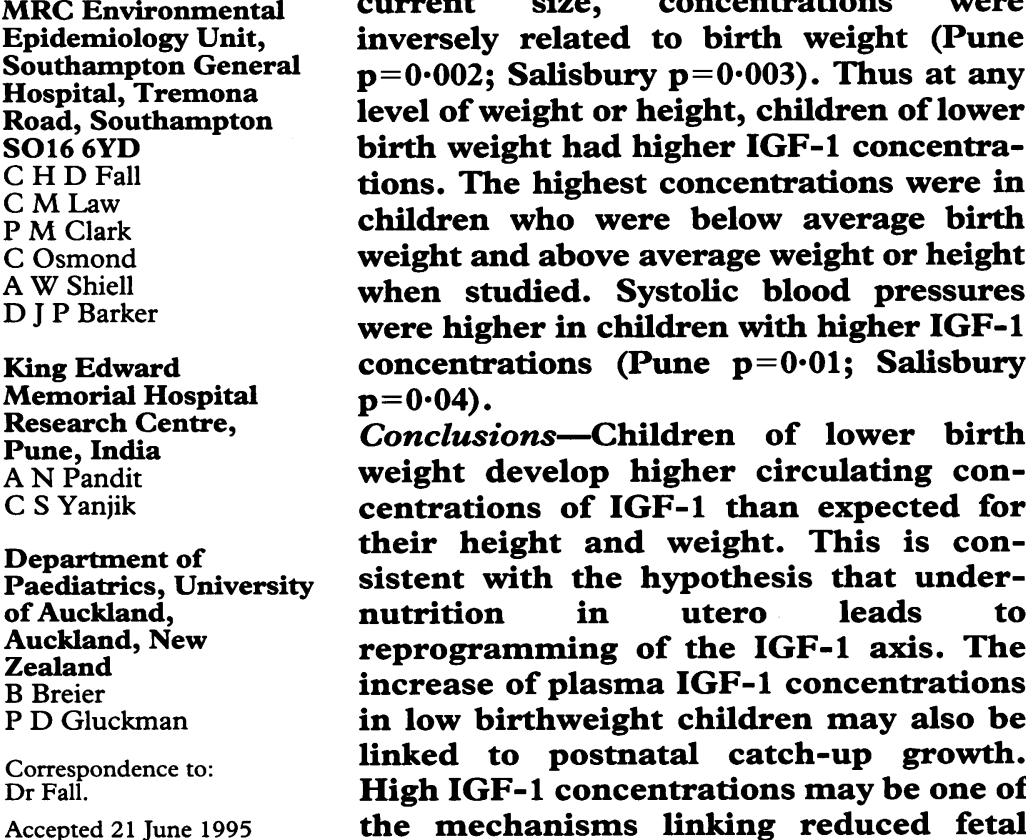

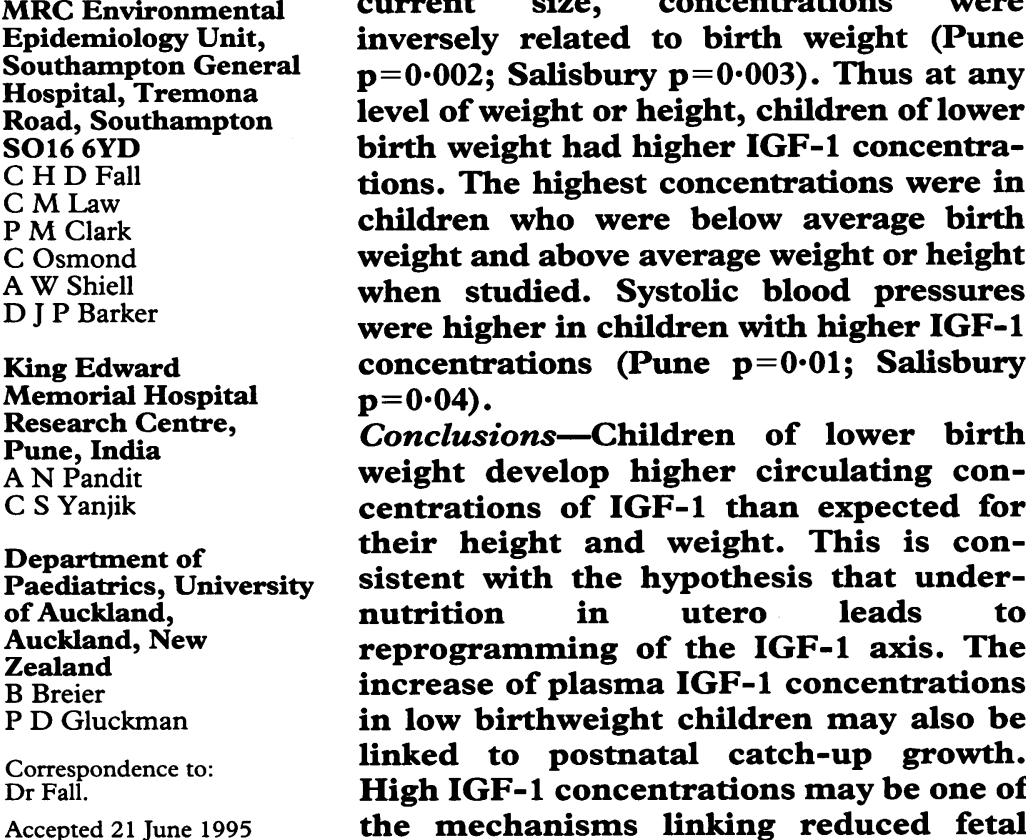

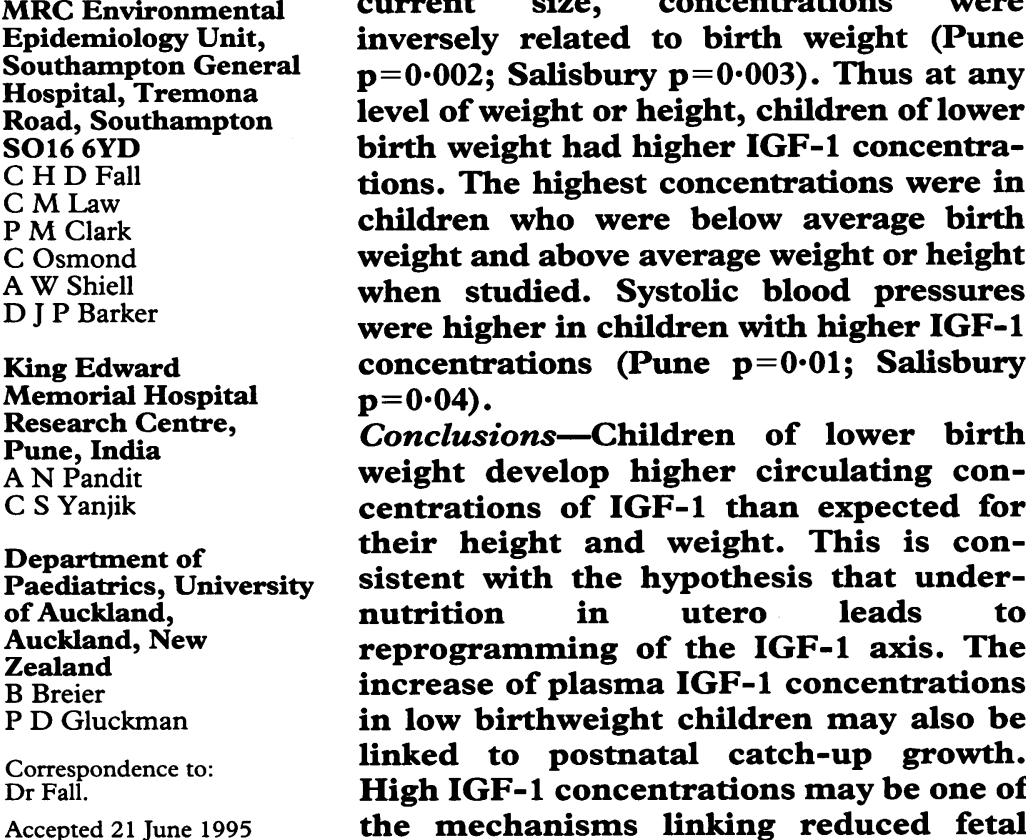

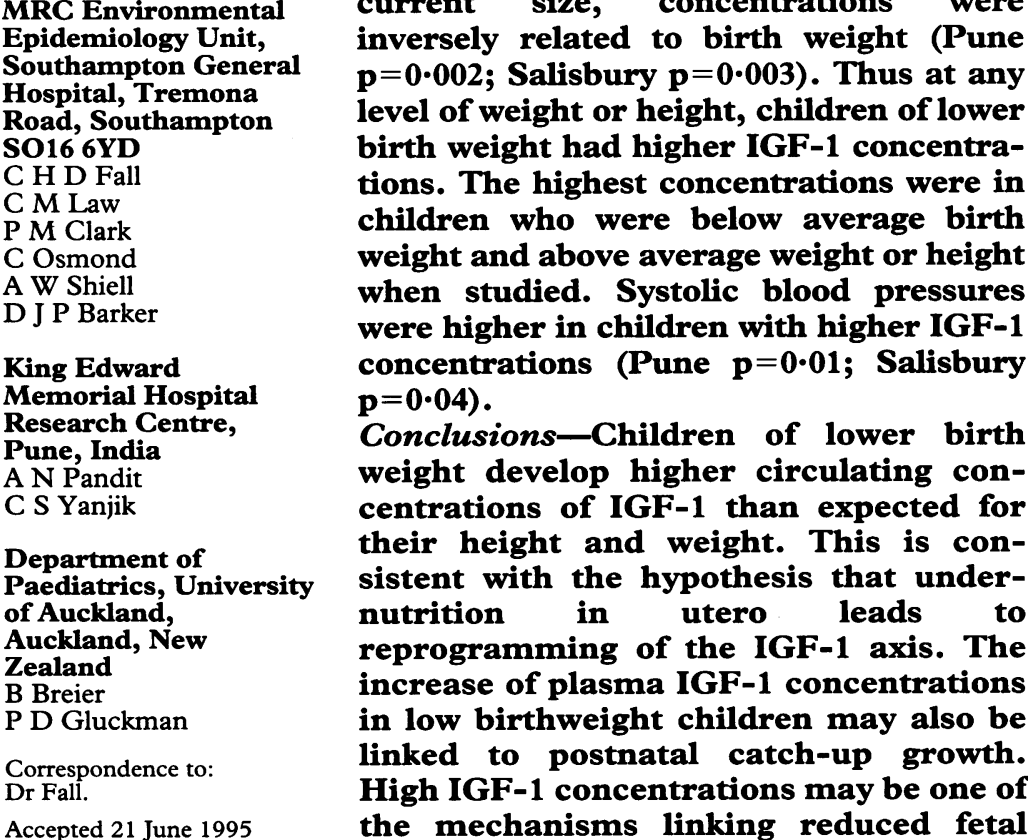

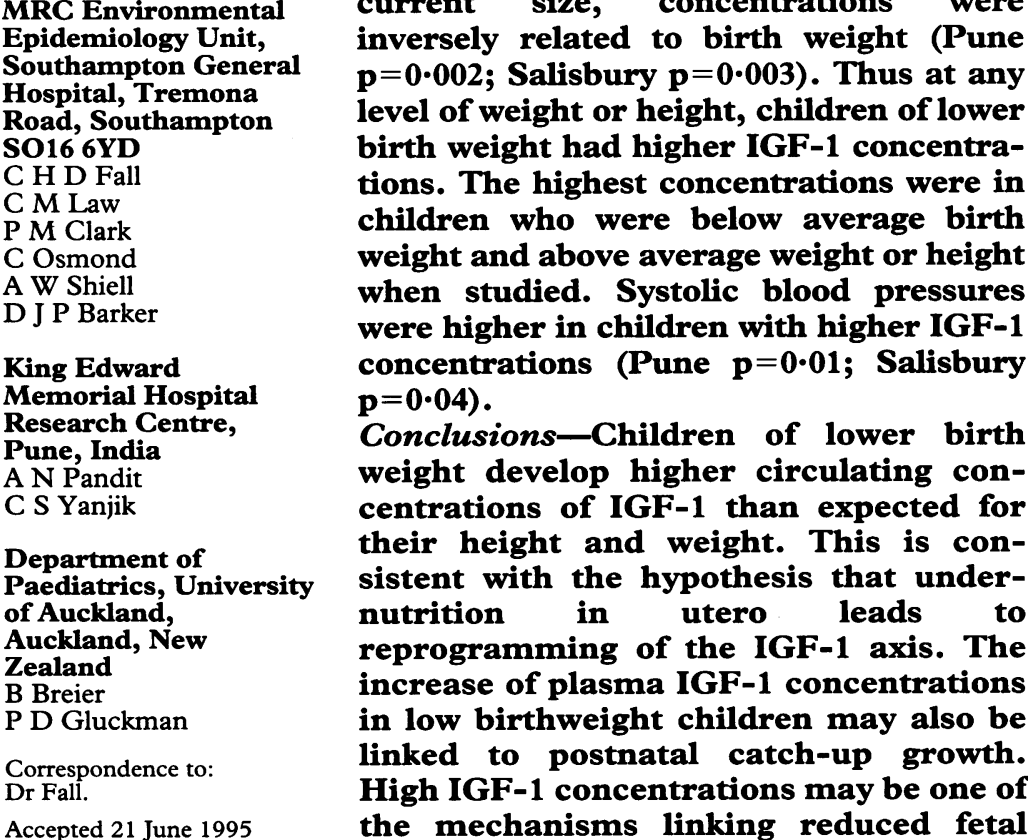

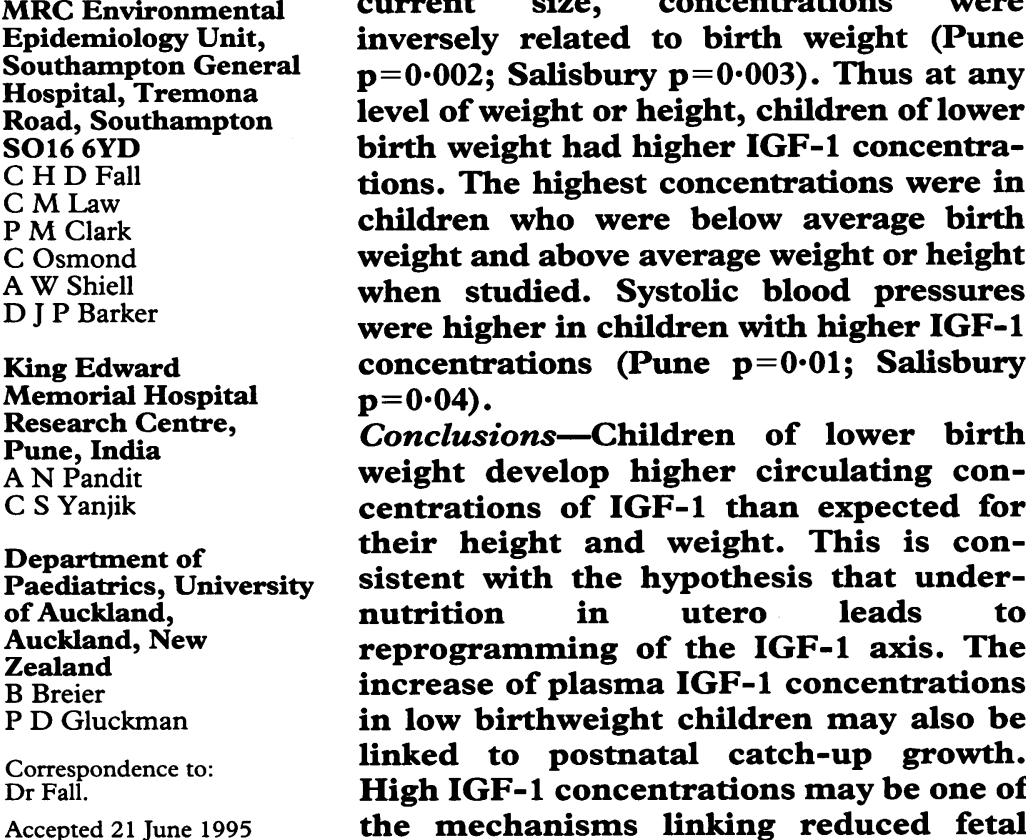

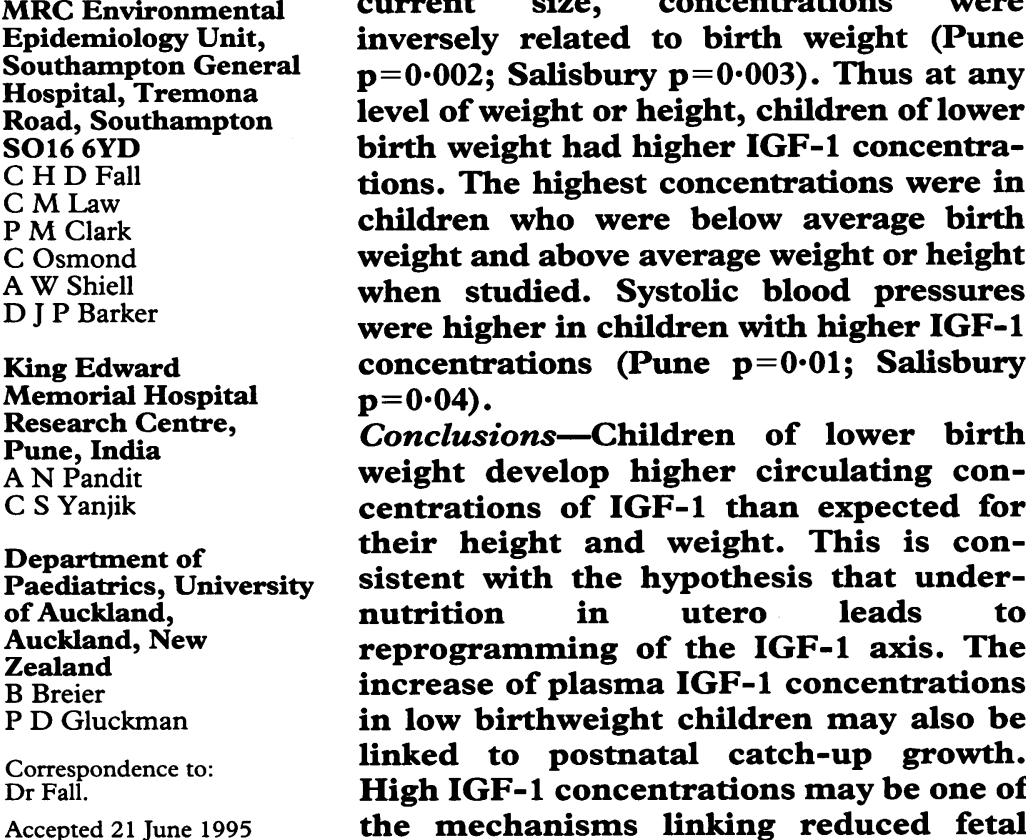

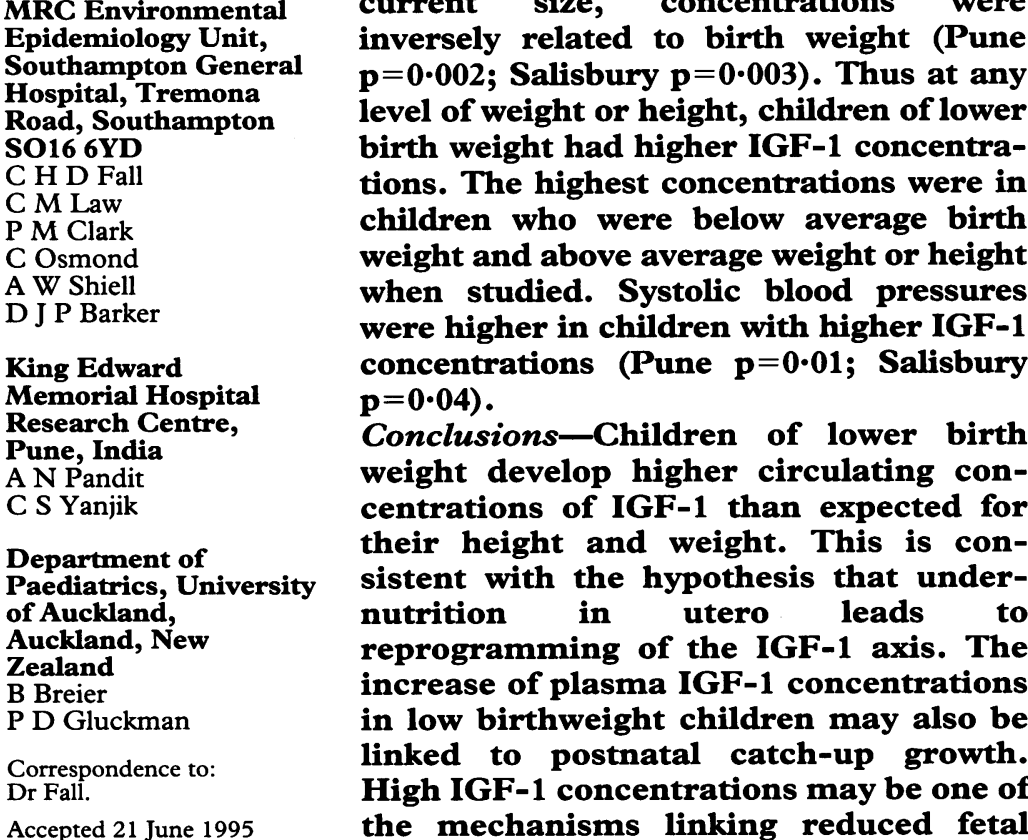


Table 1 Anthropometric data at birth and 4 years in Pune and comparison British data ${ }^{\star}$; values are median (3rd, 97th centiles)

\begin{tabular}{lcc}
\hline & Boys $(n=104)$ & Girls $(n=96)$ \\
\hline Birth weight $(\mathrm{kg})$ & $2 \cdot 750$ & \\
Pune & $(2 \cdot 083,3 \cdot 600)$ & $2 \cdot 700$ \\
& $(2 \cdot 160,3 \cdot 509)$ \\
British standards & $(2 \cdot 918,4 \cdot 443)$ & $\begin{array}{l}3 \cdot 463 \\
(2 \cdot 773,4 \cdot 245)\end{array}$ \\
At 4 years: & & \\
Weight (kg) & $13 \cdot 0$ & $12 \cdot 5$ \\
Pune & $(10 \cdot 6,16 \cdot 9)$ & $(10 \cdot 0,17 \cdot 2)$ \\
British standards & $16 \cdot 5$ & $16 \cdot 3$ \\
& $(13 \cdot 1,20 \cdot 4)$ & $(13 \cdot 1,20 \cdot 2)$ \\
Height (cm) & $97 \cdot 6$ & $97 \cdot 8$ \\
Pune & $(88 \cdot 7,105 \cdot 7)$ & $(88 \cdot 1,106 \cdot 6)$ \\
& $101 \cdot 6$ & $100 \cdot 4$ \\
British standards & $(93 \cdot 6,109 \cdot 7)$ & $(92 \cdot 4,108 \cdot 6)$ \\
& &
\end{tabular}

«Standards for British children are from Gairdner and Pearson ${ }^{17}$ and Tanner et al. ${ }^{18}$

from 1998 live births listed in the labour ward register, in which birth weights are recorded routinely. We wrote to the children's parents inviting them to the hospital, where a paediatrician explained the study and obtained consent. Eighty four children were no longer living at the address listed at birth and could not be traced. The parents of $201(63 \%)$ of the remaining 320 allowed their child to take part.

Children were admitted to the KEMH, with a parent, the evening before the test, and fasted overnight. Blood pressure was measured in the left arm, during sleep, using an automated device (Dinamap), with a cuff of the recommended size for the measured mid-upper arm circumference. Two measurements were made at an interval of one minute, and the average used in the analysis. In the morning a fasting blood sample was taken after applying local anaesthetic cream (EMLA) to the venepuncture site. The child's weight was measured using a portable (Seca) scale to the nearest $0.5 \mathrm{~kg}$ and height using a wall mounted stadiometer (Microtoise) to the nearest $0.1 \mathrm{~cm}$. Ethical permission for the study was given by the KEMH ethics committee.

\section{SALISBURY}

Subjects were recruited from 431 singleton children who had been born in Salisbury Health District between July 1984 and February 1985 (total number of singleton births $=638$ ) and who had taken part in our earlier study of blood pressure at the age of 4 years. ${ }^{15}$ Information on the mother's pregnancy and delivery, and the baby's weight, length, head circumference, placental weight, and gestational age at birth were available from the obstetric records. The 370 children who were listed on the child health computer as still living in the district, and whose general practitioners gave permission, were invited by letter to take part. They were visited at home by a paediatrician or a nurse, who explained the study and obtained consent, and $250(68 \%)$ children agreed to have blood samples taken. A blood sample was taken at a second home visit, in the morning, after the child had fasted overnight. EMLA cream was applied one hour before venepuncture. The child's weight was measured to the nearest $0 \cdot 1$ $\mathrm{kg}$ using digital scales, and height to the nearest $0.1 \mathrm{~cm}$ using a portable stadiometer (Minimetre).

Blood pressure was not measured during this (7 year) study. We subsequently recontacted the children at the age of 9 years, and the 239 children still living in Hampshire, Wiltshire, or Dorset agreed to have their blood pressure measured. Pressures were measured either at school or at home, in the left arm, using an automated recorder (Dinamap) with the cuff size recommended for the measured arm circumference. After a five minute rest period, with the child seated, three measurements were taken at one minute intervals, and the average used in the analysis. The child's weight and height were measured as before. Ethical permission for the studies was obtained from the Salisbury Health Authority ethics committee.

\section{LABORATORY METHODS}

Samples suitable for laboratory analysis were obtained from 200 children in Pune and 244 children in Salisbury. Plasma IGF-1 concentrations were measured in Auckland, New Zealand, using a double antibody radioimmunoassay, after acid-ethanol cryoprecipitation. ${ }^{16}$ The primary antiserum (No 878/4) was used at a final dilution of 1:250 000. The cross reactivity of the antibody with IGF-2 and insulin was $<0.05 \%$ and $<0.001 \%$ respectively and the minimal detectable dose was 0.07 ng/tube. Recombinant human IGF-1 (batch CPG 35'126, provided by Drs K Mueller and W Maerky, Ciba-Geigy Ltd, Basel, Switzerland) was iodinated by the chloramine $T$ method. Residual IGF binding proteins were blocked by addition of an excess rhIGF-2 (50 $\mu \mathrm{g} /$ tube, Eli Lilly and Co, Indianapolis, Indiana) before addition of ${ }^{125}$ I labelled IGF-1 tracer and incubation at $4^{\circ} \mathrm{C}$ for 18 hours. The intra-assay coefficient of variation was $5 \%$ and the interassay coefficient of variation was $8 \%$, across the whole range of IGF-1 concentrations. IGF-1 values are expressed in terms of the international reference preparation (IRP IGF-1, batch 87/518).

\section{STATISTICAL METHODS}

Among the Pune children, the distribution of plasma IGF-1 concentrations was positively skewed, and values were transformed to normality using logarithms. Among the Salisbury children the distribution of IGF-1 was not markedly skewed and did not require transformation. Data were analysed by tabulation of means and multiple linear regression. Comparisons between the sexes were made using $t$ tests. Levels of significance refer to analyses of continuous variables by regression.

\section{Results}

IGF-1, SEX, AND CURRENT BODY SIZE

In Pune, the children's ages ranged from 3.7 to 
Table 2 Anthropometric data at birth and 7 and 9 years in Salisbury; values are mean (SD)

\begin{tabular}{|c|c|c|}
\hline & Boys $(n=124)$ & Girls $(n=120)$ \\
\hline \multicolumn{3}{|l|}{ At birth } \\
\hline Weight (kg) & $3.374(0.545)$ & $3 \cdot 344(0.464)$ \\
\hline Length $(\mathrm{cm})$ & $51.5(2.4)$ & $50 \cdot 8(2 \cdot 3)$ \\
\hline \multicolumn{3}{|l|}{ Head circumference } \\
\hline$(\mathrm{cm})$ & $34 \cdot 8(1 \cdot 3)$ & $34 \cdot 3(1 \cdot 3)$ \\
\hline Ponderal index $\left(\mathrm{kg} / \mathrm{m}^{3}\right)$ & $25 \cdot 3(3 \cdot 1)$ & $25 \cdot 7(3 \cdot 2)$ \\
\hline Placental weight (g) & $665(201)$ & $654(133)$ \\
\hline Gestation (weeks) & $40 \cdot 0(1 \cdot 8)$ & $40 \cdot 3(1.4)$ \\
\hline \multicolumn{3}{|l|}{ At 7 years } \\
\hline Weight (kg) & $26 \cdot 3(4 \cdot 6)$ & $25 \cdot 8(4 \cdot 1)$ \\
\hline Height $(\mathrm{cm})$ & $127 \cdot 3(6 \cdot 4)$ & $126 \cdot 2(5 \cdot 4)$ \\
\hline \multicolumn{3}{|l|}{ At 9 years $(n=239)$} \\
\hline Weight (kg) & $32 \cdot 0(6 \cdot 3)$ & $31 \cdot 4(5 \cdot 6)$ \\
\hline Height $(\mathrm{cm})$ & $135 \cdot 3(6 \cdot 7)$ & $133.9(5.7)$ \\
\hline
\end{tabular}

Length at birth was known for 210 children, head circumference for 212 , placental weight for 215 , and gestational age for 234 .

4.4 (median 4.0 years). Their birth weights and anthropometric measurements, shown in table 1, were low in comparison with British children, ${ }^{17} 18$ but similar to Indian community averages. ${ }^{19} 20$ In Salisbury the children's ages ranged from 7.3 to 8.2 years (median $7 \cdot 7$ years). Their anthropometric data at birth and 7 years are shown in table 2 .

Table 3 shows mean plasma IGF-1 concentrations in relation to height and weight, divided by approximate quartiles, for both groups of children and in boys and girls separately. Concentrations were higher in girls than boys ( $p$ value for difference: Pune $\mathrm{p}<0.001$; Salisbury $\mathrm{p}=0.5)$. Concentrations were higher in heavier and taller children of both sexes. Among the Pune children they rose by $13 \% / \mathrm{kg}$ increase in current weight $(95 \%$ confidence interval (CI) 9 to $18 ; \mathrm{p}<0.0001$ ) and by $5 \% / \mathrm{cm}$ increase in height $(95 \% \mathrm{CI} 4$ to $7 ; \mathrm{p}<0.0001)$. In a simultaneous analysis of weight and height, both measures were independently related to IGF-1 concentrations $(p=0.01$ and 0.006 respectively). Among the Salisbury children concentrations rose by $3.2 \mathrm{ng} / \mathrm{ml} / \mathrm{kg}$ increase in weight $(95 \%$ CI 2.3 to $4.1 ; \mathrm{p}<0.0001)$ and by $1.7 \mathrm{ng} / \mathrm{ml} / \mathrm{cm}$ increase in height $(95 \%$ CI 1.0 to $2.5 ; \mathrm{p}<0.0001)$. After allowing for weight, concentrations were not independently related to height ( $p$ values were $<0.0001$ and 0.9 respectively in a simultaneous analysis).

\section{IGF-1 AND BIRTH SIZE}

Plasma IGF-1 concentrations tended to fall with increasing birth weight, although the trends were not statistically significant (Pune $\mathrm{p}=0.2$; Salisbury $\mathrm{p}=0 \cdot 06$ ). Birth weight was positively correlated with current weight (Pune $\mathrm{p}=0.0006$; Salisbury $\mathrm{p}=0.03$ ) and height (Pune $p=0.002$; Salisbury $p=0.02$ ). Table 4 shows a multiple regression analysis of plasma IGF-1 concentrations with birth weight, current weight and height, and sex. In both groups of children, after allowing for current size and sex, IGF-1 concentrations were strongly inversely related to birth weight. Table 5 shows mean plasma IGF-1 concentrations according to both birth weight and current weight. Children who had been below average birth weight and were above average weight when studied had high IGF-1 concentrations. Children of above average birth weight and below average weight when studied had low concentrations. There were no statistically significant differences in the trend of IGF-1 with birth weight at different levels of current weight, nor in the trend of IGF-1 with weight at different levels of birth weight. Trends were similar in both sexes.

Among the Salisbury children, who were measured in detail at birth, IGF-1 concentrations, allowing for current weight, were higher in children who were shorter at birth $(p=0.05)$, those who had smaller head circumferences $(p=0.08)$, and those who had lower placental weights $(p=0.03)$, but were not related to ponderal index (weight/length ${ }^{3}$; $p=0.7)$ at birth. Among the 232 children whose gestational age was known, plasma IGF-1 concentrations were not related to gestation, and allowing for gestational age did not diminish the relation of IGF-1 to birth weight $(p=0.003)$, length at birth $(p=0.02)$, head circumference $(p=0.04)$, or placental weight $(p=0 \cdot 02)$.

\section{IGF-1 AND BLOOD PRESSURE}

Among the 4 year old Pune children mean (SD) systolic and diastolic blood pressures were 96 (10) $\mathrm{mm} \mathrm{Hg}$ and 49 (9) $\mathrm{mm} \mathrm{Hg}$ respectively. Blood pressure was measured at the age of 9 years in Salisbury (median age 9.3 years, range 8.9 to $9 \cdot 7$ ). Anthropometric data for the children at 9 years are shown in table 2 . Mean systolic and diastolic pressures were 99 (9) $\mathrm{mm} \mathrm{Hg}$ and 59 (6) $\mathrm{mm} \mathrm{Hg}$. As expected, in both groups, heavier children had higher blood pressures. Systolic pressure rose by $1.3 \mathrm{~mm} \mathrm{Hg}$ (95\% CI 0.5 to $2.0 ; \mathrm{p}=0.001$ ) in Pune and by $0.4 \mathrm{~mm} \mathrm{Hg}(95 \%$ CI 0.3 to $0.6 ; p<0.0001)$ in Salisbury, for each $\mathrm{kg}$ increase in current weight. Systolic pressures were also higher in

Table 3 Mean plasma IGF-1 according to height and weight; figures in parentheses are numbers of children

\begin{tabular}{lccc}
\hline \multicolumn{4}{c}{ Plasma IGF-1 (ng/ml) } \\
\cline { 2 - 4 } & Girls & Boys & All \\
\hline 4 Year old children in Pune & & \\
Height (cm) & & & \\
$\quad \leq 94 \cdot 0$ & $43(24)$ & $33(26)$ & $37(50)$ \\
$>94 \cdot 0-97 \cdot 5$ & $51(22)$ & $34(25)$ & $41(47)$ \\
$>97 \cdot 5-100 \cdot 5$ & $69(29)$ & $42(24)$ & $55(53)$ \\
$>100 \cdot 5$ & $66(21)$ & $56(29)$ & $60(50)$ \\
Weight $(\mathrm{kg})$ & & & \\
$\leqslant 11 \cdot 5$ & $43(23)$ & $25(18)$ & $34(41)$ \\
$>11 \cdot 5-12 \cdot 5$ & $56(31)$ & $36(30)$ & $45(61)$ \\
$>12 \cdot 5-14 \cdot 0$ & $55(19)$ & $48(27)$ & $51(46)$ \\
$>14 \cdot 0$ & $77(23)$ & $52(29)$ & $62(52)$ \\
All & $56(96)$ & $41(104)$ & $48(200)$ \\
SD (geometric) & $1 \cdot 7$ & $1 \cdot 7$ & $1 \cdot 7$ \\
7 Year old children & in Salisbury & & \\
Height (cm) & & & \\
$\leqslant 122$ & $104(29)$ & $104(26)$ & $104(55)$ \\
$>122-126$ & $111(28)$ & $108(23)$ & $109(51)$ \\
$>126-130$ & $128(34)$ & $121(38)$ & $124(72)$ \\
$>130$ & $131(29)$ & $124(37)$ & $127(66)$ \\
Weight (kg) & & & \\
$\leqslant 23 \cdot 0$ & $102(27)$ & $98(30)$ & $100(57)$ \\
$>23 \cdot 0-25 \cdot 5$ & $108(38)$ & $110(25)$ & $109(63)$ \\
$>25 \cdot 5-28 \cdot 0$ & $133(25)$ & $117(37)$ & $123(62)$ \\
$>28 \cdot 0$ & $137(30)$ & $135(32)$ & $136(62)$ \\
All & $119(120)$ & $116(124)$ & $117(244)$ \\
SD & 33 & 37 & 35 \\
& & & \\
\hline
\end{tabular}


Table 4 Multiple regression analysis of plasma IGF-1 concentration with birth weight and other variables

\begin{tabular}{|c|c|c|c|}
\hline Variable & $\begin{array}{l}\text { Regression } \\
\text { coefficient }\end{array}$ & $\begin{array}{l}\text { Standard } \\
\text { error }\end{array}$ & p Value \\
\hline \multicolumn{4}{|l|}{ Pune } \\
\hline Heigh & 0.0331 & 0.0111 & 0.003 \\
\hline Weight $(\mathrm{k}$ & 0.0 & 0 & 0.003 \\
\hline $\operatorname{Sex}($ boys $=0, \operatorname{girls}=1)$ & $0 \cdot 3$ & 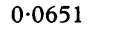 & $<0.0001$ \\
\hline Birth weight $(\mathrm{kg})$ & $-0 \cdot 2970$ & 0.0924 & 0.002 \\
\hline \multirow{2}{*}{\multicolumn{4}{|c|}{$\begin{array}{c}\text { Constant } \\
\text { y variable }=\log \text { plasma IGF-1 concentration }(\mathrm{ng} / \mathrm{ml})\end{array}$}} \\
\hline & & & \\
\hline \multicolumn{4}{|l|}{ Salisbury } \\
\hline Height (c & $0 \cdot 2$ & 0.5 & $0 \cdot 7$ \\
\hline Weight (kg) & $3 \cdot 207$ & 0.6795 & $<0.001$ \\
\hline Sex & $4 \cdot 807$ & $4 \cdot 117$ & $0 \cdot 2$ \\
\hline Birth weight $(\mathrm{kg})$ & $-12 \cdot 42$ & $4 \cdot 108$ & 0.003 \\
\hline Constant & $115 \cdot 0$ & & \\
\hline
\end{tabular}

Height, weight, and birth weight standardised by subtracting their means. Thus constant $=$ predicted IGF- 1 (logIGF- 1 in Pune) for a boy of average height, weight, and birth weight.

taller children (Pune $\mathrm{p}=0.0006 ;$ Salisbury $\mathrm{p}=0.0007$ ), although not independently of weight. Trends were similar for diastolic pressure, though weaker. There was no statistically significant relation between blood pressure and birth weight in either group of children. After allowing for current weight, systolic pressure fell by $0.6 \mathrm{~mm} \mathrm{Hg}(95 \% \mathrm{CI}-4.4$ to $3 \cdot 1$; $\mathrm{p}=0.7) / \mathrm{kg}$ increase in birth weight in Pune, and by $0.5 \mathrm{~mm} \mathrm{Hg}(95 \%$ CI -2.6 to 1.6 ; $\mathrm{p}=0.6) / \mathrm{kg}$ increase in birth weight in Salisbury.

Children with higher IGF-1 concentrations had higher systolic blood pressures (figure). Among the Pune children, systolic pressure rose by $2.2 \mathrm{~mm} \mathrm{Hg}$ as plasma IGF-1 doubled $(95 \%$ CI 0.5 to $3.9 ; \mathrm{p}=0.01)$. Among the Salisbury children, systolic pressure at 9 years rose by $3.2 \mathrm{~mm} \mathrm{Hg}(95 \%$ CI 0.2 to 6.3 ; $\mathrm{p}=0.04)$ for each $100 \mathrm{ng} / \mathrm{ml}$ increase in plasma IGF-1 concentration at 7 years. The association of systolic blood pressure and IGF-1 concentrations was not statistically significant in a simultaneous analysis with current weight (Pune $p=0 \cdot 2$; Salisbury $p=0 \cdot 7$ ). IGF-1 concentrations were not related to diastolic blood pressure.

\section{Discussion}

Consistent with the findings of others, ${ }^{21}$ and in both groups of children studied, those who were heavier and taller had higher plasma IGF-1 concentrations (table 3 ). A new finding was that at any level of current weight or height, children who were lighter at birth had higher plasma IGF-1 concentrations (tables 4 and 5). Gestational age at birth, available for the Salisbury children, was not related to IGF-1 concentrations, suggesting that the higher concentrations in lower birthweight babies are related to intrauterine growth retardation rather than premature birth. Our findings are consistent with the hypothesis that the IGF-1 axis is altered, or 'reprogrammed', in babies who were undernourished in utero, resulting in higher plasma concentrations during childhood.

With one exception, ${ }^{22}$ studies have consistently shown that plasma IGF-1 concentration and activity are low in umbilical cord blood from small for gestational age fetuses 62324 and neonates. ${ }^{25-30}$ In the early neonatal period, both high ${ }^{31} 32$ and low ${ }^{33}$ plasma IGF1 concentrations/activity in low birthweight babies have been reported. We can speculate about mechanisms by which low levels in small babies at birth might become raised postnatally. Studies in animals and humans have shown that nutrition is a dominant influence on IGF-1 concentrations prenatally, ${ }^{63-36}$ and continues to modulate concentrations postnatally, ${ }^{3738}$ undernutrition leading to reduced IGF-1 secretion and to IGF-1 resistance. ${ }^{39}$ High concentrations may be a response to adequate postnatal nutrition or alternatively, they may reflect persisting IGF-1 resistance, in an individual who experienced prenatal undernutrition. The fact that, in our study, IGF-1 concentrations were higher in low birthweight babies after controlling for current size, suggests that there is an element of IGF-1 resistance, at least to its growth promoting actions, in the lower birthweight children.

Another possible explanation for the higher concentrations in lower birthweight children is that they are mediated through growth hormone. Growth hormone becomes a major regulator of IGF-1 after birth. It stimulates synthesis and release of IGF-1, and IGF binding protein 3, which prolongs the survival of IGF-1 in circulation. ${ }^{40}$ Low birthweight babies have been shown to have high basal growth hormone concentrations and an increased growth hormone response to growth hormone releasing hormone. ${ }^{31}$

In our study the highest plasma IGF-1 concentrations were found in children who had the lowest birth weights but had attained the highest weights or heights when studied (table $5)$. The increased IGF-1 concentrations in low birthweight children may be linked to the process of catch-up growth, which occurs during infancy in many babies whose growth was reduced in utero. Catch-up growth is

Table 5 Mean plasma IGF-1 concentrations (ng/ml) according to birth weight and current weight; figures in parentheses are numbers of children

\begin{tabular}{|c|c|c|c|c|c|c|c|c|c|c|c|}
\hline \multicolumn{6}{|l|}{ Pune } & \multicolumn{6}{|l|}{ Salisbury } \\
\hline \multirow{2}{*}{$\begin{array}{l}\text { Birth weight } \\
(\mathrm{kg})\end{array}$} & \multicolumn{5}{|c|}{ Weight at 4 years $(\mathrm{kg})$} & \multirow{2}{*}{$\begin{array}{l}\text { Birth weight } \\
(\mathrm{kg})\end{array}$} & \multicolumn{5}{|c|}{ Weight at 7 years $(\mathrm{kg})$} \\
\hline & $\leqslant 11 \cdot 5$ & $>11 \cdot 5-12 \cdot 5$ & $>12 \cdot 5-14 \cdot 0$ & $>14 \cdot 0$ & All & & $\leqslant 23 \cdot 0$ & $>23 \cdot 0-25 \cdot 5$ & $>25 \cdot 5-28 \cdot 0$ & $>28 \cdot 0$ & All \\
\hline $\begin{array}{l}\leqslant 2 \cdot 5 \\
>2 \cdot 5-2 \cdot 75 \\
>2 \cdot 75-3 \cdot 0 \\
>3 \cdot 0 \\
\text { All }\end{array}$ & $\begin{array}{l}38(14) \\
30(10) \\
36(12) \\
28(5) \\
34(41)\end{array}$ & $\begin{array}{l}52(19) \\
51(14) \\
40(20) \\
38(8) \\
45(61)\end{array}$ & $\begin{array}{l}53(14) \\
68(8) \\
42(10) \\
48(14) \\
51(46)\end{array}$ & $\begin{array}{l}75(10) \\
57(12) \\
78(14) \\
48(16) \\
62(52)\end{array}$ & $\begin{array}{l}51(57) \\
49(44) \\
46(56) \\
43(43) \\
48(200)\end{array}$ & $\begin{array}{l}\leqslant 3 \cdot 0 \\
>3 \cdot 0-3 \cdot 3 \\
>3 \cdot 3-3 \cdot 6 \\
>3 \cdot 6 \\
\text { All }\end{array}$ & $\begin{array}{c}100(14) \\
100(24) \\
99(10) \\
103(9) \\
100(57)\end{array}$ & $\begin{array}{l}117(10) \\
110(17) \\
104(16) \\
108(20) \\
109(63)\end{array}$ & $\begin{array}{l}130(11) \\
131(13) \\
130(18) \\
109(20) \\
123(62)\end{array}$ & $\begin{array}{l}138(14) \\
150(12) \\
144(10) \\
125(26) \\
136(62)\end{array}$ & $\begin{array}{l}121(49) \\
118(66) \\
119(54) \\
114(75) \\
117(244)\end{array}$ \\
\hline
\end{tabular}




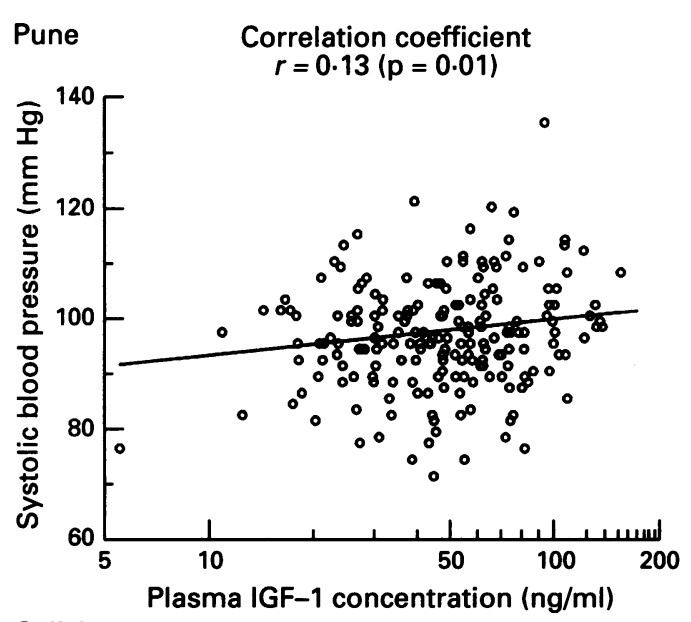

Salisbury

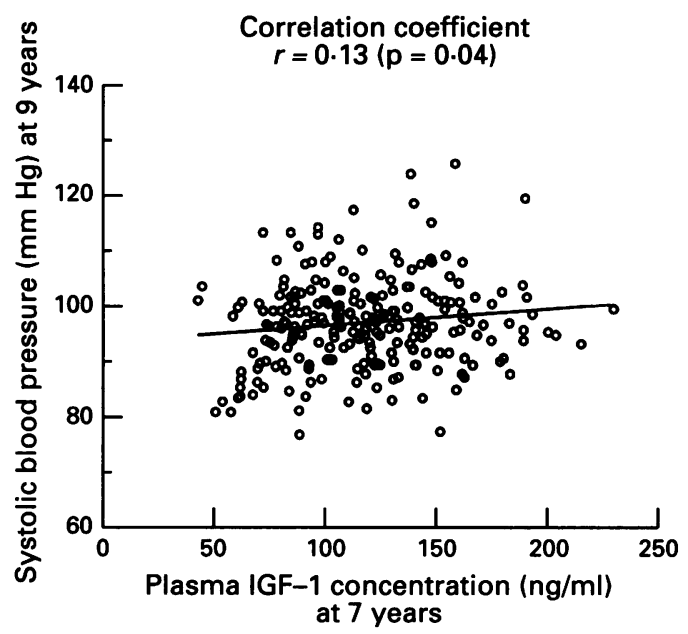

Mean systolic blood pressure according to plasma IGF-1 concentration in Pune and Salisbury.

influenced by prenatal growth, ${ }^{4142}$ and by a number of postnatal factors, especially nutrition. During their first year, low birthweight babies whose growth catches up have higher plasma IGF-1 concentrations than those who do not, although concentrations do not exceed those of higher birthweight babies of equivalent infant size. ${ }^{43} \mathrm{We}$ do not have infant growth data for our children, and where only birth size and current size are known it is not possible to conclude whether the higher IGF-1 concentrations are due to a combination of small size at birth and large current size, or to catch-up growth during a critical period in infancy. Further study is required of IGF-1 concentrations during and after catch-up growth.

High IGF-1 concentrations in low birthweight children may be analogous to the high insulin concentrations found in low birthweight adults. ${ }^{7-12}$ The high insulin concentrations in adults reflect insulin resistance, and occur in men and women who were thin, having a low ponderal index, at birth. ${ }^{8}$ Length at birth was not available for the Indian children in our study, but higher IGF-1 concentrations in the Salisbury children were associated with shortness at birth, and not with low ponderal index. This suggests that the pattern of fetal growth associated with altered IGF-1 concentrations differs from that associated with altered insulin concentrations.

IGF-1 concentrations were low in the Indian children in comparison with those of European children of the same age measured using the same assay method, ${ }^{21}$ while concentrations in the Salisbury children were similar. This is consistent with the smaller size of Indian children. Their low height and weight are likely to reflect a degree of chronic undernutrition, although none showed clinical signs of acute undernutrition. Poorer nutrition and growth may explain the greater positive skewness of the distribution of IGF-1 concentrations in the Indian, compared with the British children in our study, requiring log transformation of the data. The consistency of our findings in both groups of children shows that the relationship of high IGF-1 concentrations to low birth weight does not result from the poorer growth of the Indian children. The relationship of IGF-1 concentrations to current size differed in the two groups of children. Among the Indian children increased height and weight both, independently, predicted higher IGF-1 concentrations, while among the Salisbury children, although concentrations rose with increasing height and weight, only weight remained a significant predictor of IGF-1 in a simultaneous regression analysis. We are unable to explain this difference. Published studies of European children report that height and weight (or body mass index) are positively related to IGF-1 concentrations, but do not discuss the interrelationships of height and weight. $^{21} 4445$ In our study, IGF-1 concentrations were higher in girls than in boys, the difference being more marked, and statistically significant, in the 4 year old Indian children. European studies consistently report higher concentrations in girls compared with boys, despite their smaller size, although the differences are not significant. ${ }^{44-46}$ We have no explanation for the stronger sex difference among the Indian children.

We did not find the inverse relationship of systolic blood pressure with birth weight in the 4 year old Indian children that has been found in European children of similar age, ${ }^{47}$ and in the Salisbury children when studied at 4 years. ${ }^{15}$ In European studies this relationship becomes evident after infancy, disappears during puberty, and grows stronger with increasing adult age. ${ }^{48}$ The relationship may be absent in the Indian population studied, or the age at which it appears may differ. We plan to measure blood pressure in the same group of children at a later age, and are currently studying blood pressure in Indian adults. The non-significant relationship of systolic pressure to birth weight at the age of 9 in the Salisbury children is consistent with the findings of the Brompton longitudinal study of blood pressure in children. ${ }^{49}$ Systolic pressure was significantly inversely related to birth weight at the age of 4 years, but the relationship was weaker, and not statistically significant at 9 years. This may be because the children were approaching puberty, during 
which the tracking of blood pressure is known to be perturbed. ${ }^{48}$

In both groups of children plasma IGF-1 concentrations were positively correlated with systolic blood pressure. We do not know whether this is just an association mediated indirectly through current body size, or whether it reflects a biological interaction between IGF-1 and systolic blood pressure. Lever and Harrap have suggested that growth factors which determine somatic growth also determine blood pressure in childhood, ${ }^{50}$ and that essential hypertension may be initiated by the action of growth factors on blood vessel development during childhood. IGF-1 is thought to be important for the growth of blood vessels, and is mitogenic for vascular smooth muscle cells in culture. ${ }^{51-53}$

In conclusion we have shown that, after allowing for current size, 4 year old Indian children, and 7 year old British children, of lower birth weight have higher circulating concentrations of IGF-1. At present the mechanisms responsible for this, and the possible consequences on cardiovascular development are unknown.

In Pune, we are grateful to social workers A Vairagar, K N Raut, and $V$ Gaikwad, who traced the subjects, and to research nurses Gokhale and Jadhav. In Salisbury we thank the Department of Community Child Health, Salisbury Health District, the general practitioners who helped us to contact the subjects, and research nurse I Webb. We thank computer staff $\mathrm{V} M$ Joshi (Pune), and G Wield and V Cox (Southampton), and C Gibson (Auckland) for assistance with assays. The study was funded by the Wellcome Trust.

1 Osmond C, Barker DJP, Winter PD, Fall CHD, Simmonds SJ. Early growth and death from cardiovascular disease in women. BMF 1993; 307: 1519-24.

2 Barker DJP, Osmond C, Simmonds SJ, Wield GA. The relation of small head circumference and thinness at birth to death from cardiovascular disease in adult life. $B M F$ 1993; 306: 422-6.

3 Barker DJP, Bull AR, Osmond C, Simmonds SJ. Fetal and placental size and risk of hypertension in adult life. $B M \mathcal{F}$ placental size and risk

4 Barker DJP. Mothers, babies and disease in later life. London: BMJ Publication Group, 1994

5 Barker DJP, Gluckman PD, Godfrey KM, Harding JE, Owens JA, Robinson JS. Fetal nutrition and cardiovascular disease in adult life. Lancet 1993; 341: 938-41.

6 Langford K, Blum W, Nicolaides K, Jones J, McGregor A, Miell J. The pathophysiology of the insulin-like growth factor axis in fetal growth failure: a basis for programming by undernutrition? Eur f Clin Invest 1994; 24: 851-6.

7 Hales CN, Barker DJP, Clark PMS, Cox LJ, Fall CHD, Osmond C. Fetal and infant growth and impaired glucose tolerance at age 64. BMF 1991; 303: 1019-22.

8 Phillips DIW, Barker DJP, Hales CN, Hirst S, Osmond C. Thinness at birth and insulin resistance in adult life. Diabetologia 1994; 37: 150-4.

9 Barker DJP, Hales CN, Fall CHD, Osmond C, Phipps K, Clark PMS. Type 2 (non-insulin-dependent) diabetes mellitus, hypertension and hyperlipidaemia (syndrome $\mathrm{X}$ ): relation to reduced fetal growth. Diabetologia 1993; 36: relation.

10 Valdez R, Athens MA, Thompson GH, Bradshaw BS, Stern MP. Birthweight and adult health outcomes in a biethnic US population. Diabetologia 1994; 37: 624-31.

11 Fall CHD, Osmond C, Barker DJP, et al. Fetal and infant growth and cardiovascular risk factors in women. $B M F$ 1995; 310: 428-32.

12 McKeigue PM, Leon DA, Berglund L, Mohsen R, Lithell HO. Relationship of birthweight and ponderal index to non-insulin-dependent diabetes and insulin response to glucose challenge in men aged 50-60 years. Diabet Med 1994; 11: A17, S17 (abstract)

13 Yajnik CS, Fall CHD, Vaidya U, et al. Fetal growth and glucose and insulin metabolism in four year old Indian children. Diabet Med 1995; 12: 330-6.

14 Law CM, Gordon GS, Shiell AW, Barker DJP, Hales CN Thinness at birth and glucose tolerance in seven-year old children. Diabet Med 1995; 12: 24-9.

15 Law CM, Barker DJP, Bull AR, Osmond C. Maternal and fetal influences on blood pressure. Arch Dis Child 1991; 66: $1291-5$.

16 Breier BH, Milsom SR, Blum W, Schwander J, Gallaher BW, Gluckman PD. Insulin-like growth factors and their binding proteins in plasma and milk after growth hormone stimulated galactopoiesis in normally lactating women. Acta Endocrinol (Copenh) 1993; 129: 427-35.

17 Gairdner D, Pearson J. Birthweight standards. Arch Dis Child 1985; 60: 1202 .

18 Tanner JM, Whitehouse RH, Takaishi M. Standards from birth to maturity for height, weight height velocity and weight velocity: British children, 1965. Part II. Arch Dis Whight velocity: British

19 Mohan Man, Shiv Prasad SR, Chellani HK, Kapani V. Intrauterine growth curves in north Indian babies: weight, length, head circumference and ponderal index. Indian Pediatr 1990; 27: 43-51.

20 Indian Council of Medical Research. Growth and physical development of Indian infants and children. New Delhi, India: Indian Council of Medical Research, 1984

21 Blum WF, Albertsson-Wikland K, Rosberg S, Ranke MB. Serum levels of Insulin-like growth factor I (IGF-I) and IGF binding protein 3 reflect spontaneous growth hormone secretion. f Clin Endocrinol Metab 1993; 76: 1610-6.

22 Wang HS, Lim J, English J, Irvine L, Chard T. The concentration of insulin-like growth factor-1 and insulinlike growth factor-binding protein-1 in human umbilical cord serum at delivery: relation to fetal weight. cord serum at delivery: relatic

23 Lassarre C, Hardouin S, Daffos F, Forestier F, Frankenne $F$, Binoux $M$. Serum insulin-like growth factors and insulin-like growth factor binding proteins in the human insulin-like growth factor binding proteins in the human
fetus; relationships with growth in normal subjects and in fetus; relationships with growth in normal subjects and in subjects with intrauter

24 Ashton IK, Zapf J, Einschenk I, MacKenzie IZ. Insulin-like growth factors (IGF) 1 and 2 in human foetal plasma and relationship to gestational age and foetal size during midpregnancy. Acta Endocrinol (Copenh) 1985; 110: 558-63.

25 Gluckman PD, Brinsmead MW. Somatomedin in cord blood: relationship to gestational age and birth size. $7 \mathrm{Clin}$ Endocrinol Metab 1976; 43: 1378-81.

26 Ashton IK, Vesey J. Somatomedin activity in human cord plasma and relationship to birth size, insulin, growth
hormone and prolactin. Early Hum Dev 1978; 2: 115-22.

27 Foley TP, DePhilip R, Perricelli A, Miller A. Low somatomedin activity in cord serum from infants with intra-uterine growth retardation. 7 Pediatr 1980; 96: 605-10.

28 Bennett A, Darrell M, Wilson M, et al. Levels of insulin-like growth factors I and II in human cord blood. F Clin Endocrinol Metab 1983; 57: 609-12.

29 Theriot-Prevost G, Daffos F, Forestier F. Serum somatomedin-C and bioassayable growth-promoting activity (thymidine activity) in appropriate and small-forgestational age human newborns. Acta Endocrinol (Copenh) 1985; 110: 32-5

30 Verhaege J, Van Bree R, Herck EV, Laureys J, Bouillon R, Van Assche FA. C-peptide, insulin-like growth factors I and II, and insulin-like growth factor binding protein-1 in umbilical cord serum: correlations with birthweight. $A m \mathcal{F}$ Obstet Gynecol 1993; 169: 89-97.

31 Deiber M, Chatelain P, Naville D, Putet G, Salle B. Functional hyper-somatotropism in small for gestational Functional hyper-somatotropism in small for gestational 68: $232-3$

32 Seminara S, Becherucci P, Chiccoli A, Poggi G, Bettini F, Paparo M, et al. Insulin-like growth factor 1 in normal and low birth weight newborns. Acta Paediatr Scand 1994; 356 (suppl): 126

33 Tato L, Dal Moro A, Piemont G, et al. A longitudinal study of plasma somatomedin activity in full-term, pre-term and small-for-gestational age newborns. Biol Neonate 1981; 39: $160-4$.

34 Gluckman PD. Fetal growth: an endocrine perspective. Acta Paediatr Scand Suppl 1989; 349: 21-5.

35 Oliver MH, Harding JE, Breier BH, Evans PC, Gluckman PD. Glucose but not a mixed amino acid infusion regulates plasma insulin-like growth factor-1 concentrations in fetal sheep. Pediatr Res 1993; 34: 62-5.

36 Straus DS, Ooi GT, Orlowski CC, Rechler MM Expression of the genes for insulin-like growth factor-1 Expression of the genes for insulin-like growth factor-1
(IGF-1), IGF-II, and IGF-binding proteins- 1 and 2 in fetal rat under conditions of intra-uterine growth retardafetal rat under conditions of intra-uterine growth retardation caused

37 Clemmons DR, Underwood LE. Nutritional regulation of IGF-1 and IGF binding proteins. Annu Rev Nutr 1991; 11: $393-412$

38 Straus DS. Nutritional regulation of hormones and growth factors that control mammalian growth. FASEB f 1994; 8: 6-12.

39 Thissen JP, Underwood LE, Maiter D, Maes $M$, Clemmons DR. Failure of IGF-1 infusion to promote growth in protein-restricted rats despite normalisation of serum IGF-1 concentrations. Endocrinology 1991; 128: 885-90.

40 Langford KS, Miell JP. The insulin-like growth factor$1 /$ binding protein axis: physiology, pathophysiology and therapeutic manipulation. Eur $\mathcal{F}$ Clin Invest 1993; 23: 503-16.

41 Villar J, Smeriglio V, Martorell R, Brown CH, Klein RE. Heterogeneous growth and mental development of intrauterine growth retarded infants during the first 3 years of life. Pediatrics 1984; 74: 783-91.

42 Holmes GE, Miller HC, Hassanein K, Lansky SB, Goggin JE. Postnatal somatic growth in infants with atypical fetal JE. Postnatal somatic growth in infants with atypical feta
growth patterns. Am f Dis Child 1977; 131: 1078-83. 
43 Thierot-Prevost G, Boccara JF, Francoual C, Badoual J, Job JC. Serum insulin-like growth factor 1 and serum growthpromoting activity during the first post-natal year in infants with intra-uterine growth retardation. Pediatr Res 1988; 24: 380-3.

44 Bala RM, Lopatka J, Leung A, McCoy E, McArthur RG Serum immunoreactive somatomedin levels in normal
adults, pregnant women at term, children at various ages, adults, pregnant women at term, children at various ages, and children with constitutionally dela

45 Juul A, Bang P, Hertel NT, et al. Serum insulin-like growth factor-1 in 1030 healthy children, adolescents and adults: relation to age, sex, stage of puberty, testicular size and body mass index. F Clin Endocrinol Metab 1994; 78: 744-52.

46 Argente J, Barrios V, Pozo J, et al. Normative data for insulin-like growth factors (IGFs), IGF-binding proteins, and growth hormone binding protein in a healthy Spanish pediatric population: age- and sex-related changes. $\mathcal{f}$ Clin Endocrinol Metab 1993; 77: 1522-8.

47 Whincup PH, Cook DG, Shaper AG. Early influences on blood pressure: a study of children aged 5-7 years. $B M \mathcal{F}$ 1989; 299: 587-91.

48 Law CM, Barker DJP. Fetal influences on blood pressure. f Hypertens 1994; 12: 1329-32.

49 Law CM, de Swiet M, Osmond C, et al. Initiation of hypertension in utero and its amplification throughout life. tension in utero and its amplification throughout life.

50 Lever AF, Harrap SB. Essential hypertension: a disorder of growth with origins in childhood. $\mathcal{F}$ Hypertens 1992; 10: 101-20

51 Ferns GAA, Motani AS, Anggard EE. The insulin-like growth factors: their putative role in atherogenesis. Artery 1991; 18: 197-225.

52 King GL, Goodman D, Buzney S, Moses A, Kahn CR. Receptors and growth-promoting effects of Insulin and Insulin-like growth factors on cells from bovine retinal capillaries and aorta. $\mathcal{f}$ Clin Invest 1985 ; 75: 1028-36.

53 Nakao-Hayashi J, Ito $\mathrm{H}$, Kanayasu $T$, Morita I, Murota S. Stimulatory effects of insulin and insulinlike growth factor 1 on migration and tube formation by vascular endothelial cells. Atherosclerosis 1992; 92: 141-9. 